ISSN: 0514-7336

DOI: http://dx.doi.org/10.14201/zephyrus201882119148

\title{
LAS CERÁMICAS PINTADAS CON BICROMÍA POSCOCCIÓN DE LA VERTIENTE ATLÁNTICA IBÉRICA
}

\section{Post-firing painted bichrome ware from the Atlantic Iberian façade}

\author{
Sebastián Celestino Pérez*, Esther Rodríguez González* e Inmaculada Donate Carretero**
}

* Instituto de Arqueología (CSIC-Junta de Extremadura). Plaza de España, 15. 06800 Mérida. Correo-e: scelestino@

iam.csic.es; esther.rodriguez@iam.csic.es. ID ORCID: 0000-0002-2050-7090;0000-0002-5813-9035

** Servicio de Conservación, Restauración y Estudios Cientificos del Patrimonio Arqueológico-Univ. Autónoma de Madrid. Ciudad Universitaria de Cantoblanco. 28049 Madrid. Correo-e: inmaculada.donate@uam.es. ID ORCID: 0000-0002-3644-5269

Recepción: 29/07/2017; Revisión: 17/01/2018; Aceptación: 26/03/2018

RESUMEN: Se presentan los resultados de los análisis realizados sobre un lote de cerámicas elaboradas a mano y decoradas con pintura bícroma procedentes de la vertiente atlántica de la Península Ibérica. Los análisis se realizaron tras el hallazgo de un nuevo ejemplar encontrado sobre una cabańa del Bronce Final en el yacimiento de Cerro Borreguero, en Zalamea de la Serena (Badajoz), que a su vez ha permitido ahondar en la cronología, dispersión geográfica e interpretación de estos vasos. Los fragmentos seleccionados fueron analizados con el objetivo de identificar los componentes de sus pastas, así como los pigmentos que conforman su policromía, para lo cual se llevaron a cabo análisis de difracción de Rayos X-policristal, microscopía electrónica de barrido (MEB) para caracterizar morfológica, estructural y composicionalmente la superficie de las cerámicas; $y$, por último, un análisis por energía dispersiva de Rayos $\mathrm{x}$. Con los datos obtenidos hemos podido concluir que estas cerámicas comparten elementos formales y decorativos que son característicos, fundamentalmente, de la vertiente atlántica de la Meseta Norte y Extremadura en el tránsito entre el Bronce Final y la i Edad del Hierro, donde además parece que se encuentra su origen.

Palabras clave: Cerro Borreguero; análisis de pastas; análisis de pigmentos; Bronce Final; I Edad del Hierro; Meseta Norte; Extremadura.

АвSTRACT: In this paper, we present the results of a series of analyses of a group of handmade wares with bichrome decoration from the Atlantic Iberian Peninsula. The analyses have been conducted after the finding of a new case from a Final Bronze Age hut at Cerro Borreguero (Zalamea de la Serena, Badajoz). This occurrence allowed us to delve into the chronology, geographical dispersion, and interpretation of these wares. The selected fragments were analyzed with the objective of identifying the components of their pastes and polychrome pigments. Analysis of energy dispersive X-ray, scanning electron microscopy (SEM) and X-ray diffraction-polycrystal were carried out in order to characterize morphologically, structurally, and compositionally the surface of the ceramics. With the obtained data we have been able to conclude that these ceramics share formal and decorative elements that are characteristic of the Atlantic area of the Northern Meseta and Extremadura during the transition between the Final Bronze Age and the Early Iron Age, where they probably originated.

Key words: Cerro Borreguero; paste analysis; pigment analysis; Late Bronze Age; Early Iron Age; Northern Meseta; Extremadura. 


\section{El yacimiento de Cerro Borreguero (Zalamea de la Serena, Badajoz) como punto de partida ${ }^{1}$}

El hallazgo de un vaso con una cuidada decoración pintada en el nivel de amortización de una cabaña ovalada sobre la que se construyó, hacia finales del s. viII a. C., un edificio de planta angular nos ha permitido documentar por vez primera en el valle del Guadiana la transición entre el Bronce Final y la I Edad del Hierro. El vaso en cuestión apareció en 2015, en la que hasta ahora ha sido la última campaña de excavación en el Cerro Borreguero, en el término municipal de Zalamea de la Serena (Badajoz), un enclave que se puede considerar como el antecedente de Cancho Roano, del que tan solo dista $2,5 \mathrm{~km}$ y al que le une el curso del Ortiga, uno de los principales afluentes del Guadiana. Una breve información del yacimiento se ha dado a conocer recientemente (Celestino y Rodríguez González, 2018), por lo que nos centraremos en las fases más antiguas del yacimiento para contextualizar el vaso pintado en cuestión y ahondar sobre su cronología y significado.

La Fase I de Cerro Borreguero se corresponde con una construcción romana que alteró los estratos inferiores, aunque se han podido reconstruir las plantas de los tres edificios más antiguos, los dos primeros de época protohistórica -Fases IIa y IIb- y una cabaña adscrita al Bronce Final -Fase III-. La Fase IIa se asocia al último momento de ocupación del enclave en la I Edad del Hierro, hacia mediados del s. vi a. C.; es en este momento cuando se fecha la amortización de todas sus estancias mediante el relleno con piedras de granito irregulares y sin trabar para después tapar todo el espacio con una gruesa y tupida capa de arcilla roja que es lo que le confiere al yacimiento su apariencia tumular. El edificio de esta fase está compartimentado por una serie de ámbitos de los que nos interesa la habitación 100 o H-100, de 5 x 6 m de superficie, si bien su parte occidental se pierde bajo la potente terraza romana.

1 Este trabajo se inserta dentro del proyecto del Plan Estatal de Investigación I + D Construyendo Tarteso. Análisis constructivo, espacial y territorial de un modelo arquitectónico en el valle medio del Guadiana (HAR2015-63788-P).
La habitación se caracteriza por tener un banco corrido de adobe en su lado oriental, por conservar en su centro un gran hogar circular de adobe con focus central y por tener los suelos pavimentados por una sucesión de finas capas de arcilla roja. Sobre este suelo rojo se documentó el elemento más sobresaliente de la estancia: una banda blanca de 12 $\mathrm{cm}$ de anchura y de tendencia ovalada que recorre la superficie de la habitación en sentido este-oeste hasta perderse bajo las terrazas romanas (Celestino y Rodríguez González, 2018: 176, fig. 6). La banda se realizó practicando una pequeña zanja de $5 \mathrm{~cm}$ de profundidad en el suelo rojo de la habitación rellanada posteriormente con arcilla amarillenta y, por último, pintada de blanco con caolín. En realidad, la banda blanca señalaba la cabaña ovalada de la fase anterior, Fase III, donde se hallaron los fragmentos de cerámica pintada poscocción objeto de análisis en este trabajo. Por su parte, la Fase IIb es de gran interés por cuanto documenta la transición entre la construcción de la cabańa oval de la Fase iII y la primera construcción cuadrangular. Su aliciente radica, precisamente, en la relación directa que tiene esta primera construcción cuadrangular con la cabaña oval que, aunque construida en la fase anterior, se mantuvo en uso junto a este nuevo edificio cuadrangular.

Por último, la Fase III se corresponde con la primera ocupación del Cerro Borreguero, una cabaña oval asentada sobre una suave elevación del terreno (Celestino y Rodríguez González, 2018: 178, fig. 8) que coincide con la banda blanca diseñada sobre el suelo de arcilla roja de la habitación principal de la Fase ira. La cabaña tiene una superficie de $30 \mathrm{~m}^{2}$ y sus cimientos están construidos con cantos rodados irregulares trabados con arcilla de hasta 60 $\mathrm{cm}$ de altura y una anchura que varía entre los 60 y los $70 \mathrm{~cm}$. Tanto la superficie de los cimientos como el interior de la cabaña conservan restos de arcilla de color naranja procedentes del alzado de sus muros. En el centro de la cabaña se construyó un hogar que fue respetado en las fases siguientes, por lo que el hogar de la Fase ira no es sino la prolongación de ese hogar primigenio. El uso de la cabaña se ha podido establecer en los ss. X-IX cal AC 
gracias al análisis de $\mathrm{C} 14$ realizado sobre muestras de carbón aparecido en el interior de la misma; la muestra, calibrada -95\%-, aporta una cronología de Beta-406622: $2740 \pm 30$ вр, cal AC 970-960/cal AC 930-820. Por último, la cabaña fue clausurada y amortizada a finales del s. viII a. C. para construir sobre ella el edificio de la Fase ira; sin embargo, su carácter singular propició que su clausura fuera acompañada de un ritual relacionado con el vaso que aquí estudiamos.

La cabaña del Cerro Borreguero es por el momento la única completa y registrada de la cuenca media del Guadiana, si bien su importancia arqueológica radica principalmente en que por vez primera se ha podido documentar la transición entre el Bronce Final y la I Edad del Hierro a través de la arquitectura, evidenciada a partir de la evolución de la cabańa oval a la arquitectura cuadrangular, conviviendo ambas en ese momento de transición; una evolución que ya ha sido documentada en otros yacimientos peninsulares en fechas afines (Celestino y Rodríguez González, 2017: 174; Rodríguez González, 2018: 68 y ss.).

\section{Un vaso para un ritual}

La transición arquitectónica entre la cabaña y el primer edificio de muros rectos está marcada por la aparición de una cazuela a mano pintada tras su cocción y hallada sobre los cimientos de la construcción oval (Fig. 1), marcando así el momento de amortización de la misma. Este tipo de producciones han sido documentadas en buena parte de la Meseta Norte y los valle medios del Tajo y el Guadiana, donde su mejor expresión es la necrópolis de Medellín, de donde el tipo toma el nombre (Almagro-Gorbea, 1977). La cazuela de Cerro Borreguero es de factura muy cuidada, con el borde abierto y la sección muy fina, pues apenas alcanza los $2 \mathrm{~mm}$ de grosor. Su pasta se fabricó con un alto contenido en cuarzo y fue sometida a cocción reductora. Una vez cocida, toda la superficie de la cazuela recibió una fina capa de pintura roja sobre la que se diseñó la decoración geométrica realizada ahora con un pigmento amarillo. Entre los motivos decorativos destacan los enrejados que recuerdan a los trenzados de cestería, así como metopas que encierran diseños geométricos menores. Destaca la sucesión de motivos en forma de 's', a modo de ánades, que decoran la suave carena que marca la zona central del cuerpo del vaso. La cazuela no está completa, pues falta su base y buena parte del contorno, pero es de suponer que el resto se encuentra sobre los cimientos de la mitad de la cabaña que se pierde bajo la terraza romana.

La cazuela ha sido analizada y restaurada en el Laboratorio del Servicio de Conservación, Restauración y Estudios Científicos del Patrimonio Arqueológico -SECYR- de la Univ. Autónoma de Madrid -UAM-. Las técnicas empleadas para el análisis de la misma fueron la difracción de Rayos X-policristal -DRX-P- y la microscopía electrónica de barrido con análisis por energía dispersiva de Rayos $\mathrm{X}-\mathrm{MEB} / \mathrm{EDX}^{3}$-, utilizando en este caso el equipo del Instituto de Cerámica y Vidrio del csic. A su vez, se realizaron análisis mediante espectroscopía de plasma inducida por láser -LIBSde las piedras que afloran de la zona circundante al yacimiento para estudiar la posible procedencia de los pigmentos utilizados en la pintura de la cazuela. La conclusión de estos análisis es que con toda

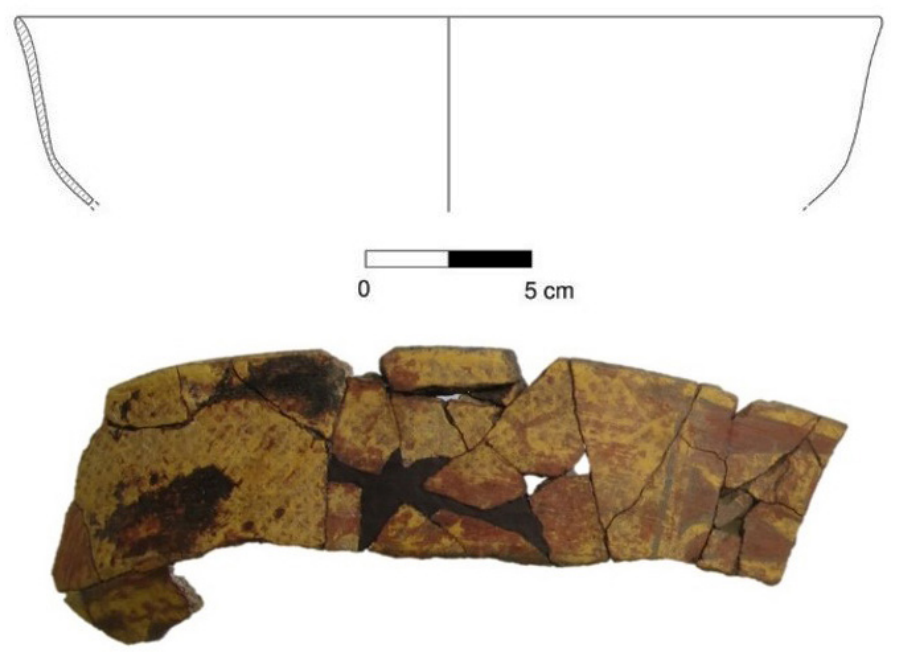

FIG. 1. Dibujo y fotografía general de la cazuela pintada poscocción hallada sobre los cimientos de la cabaña oval del Cerro Borreguero (Zalamea de la Serena, Badajoz). 

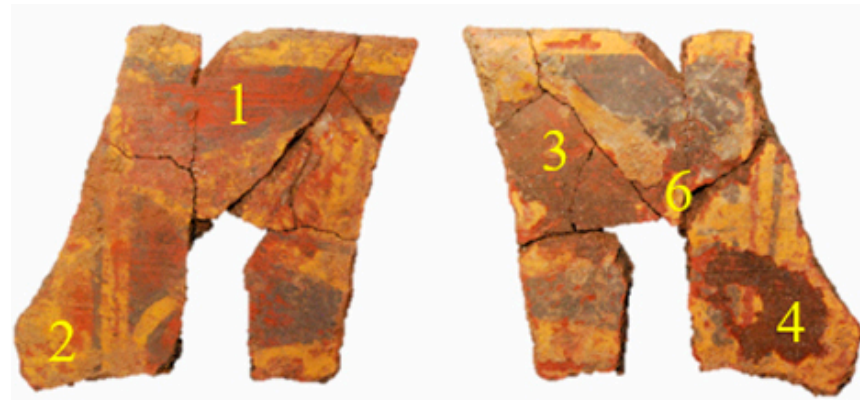

Ref. 509
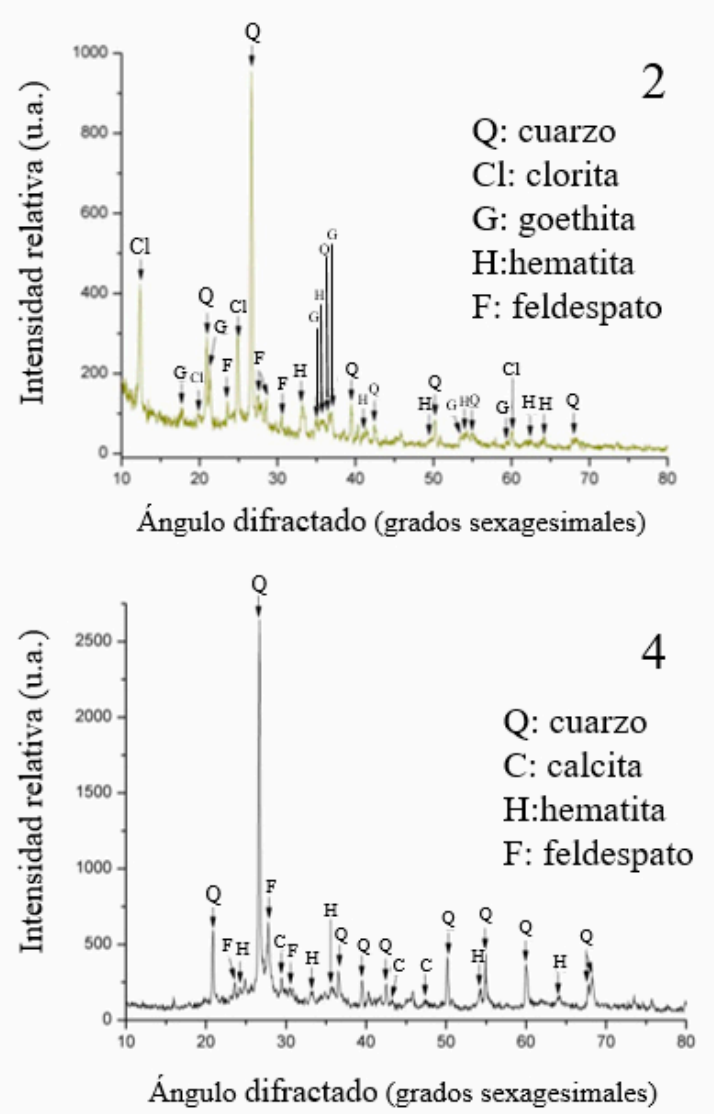
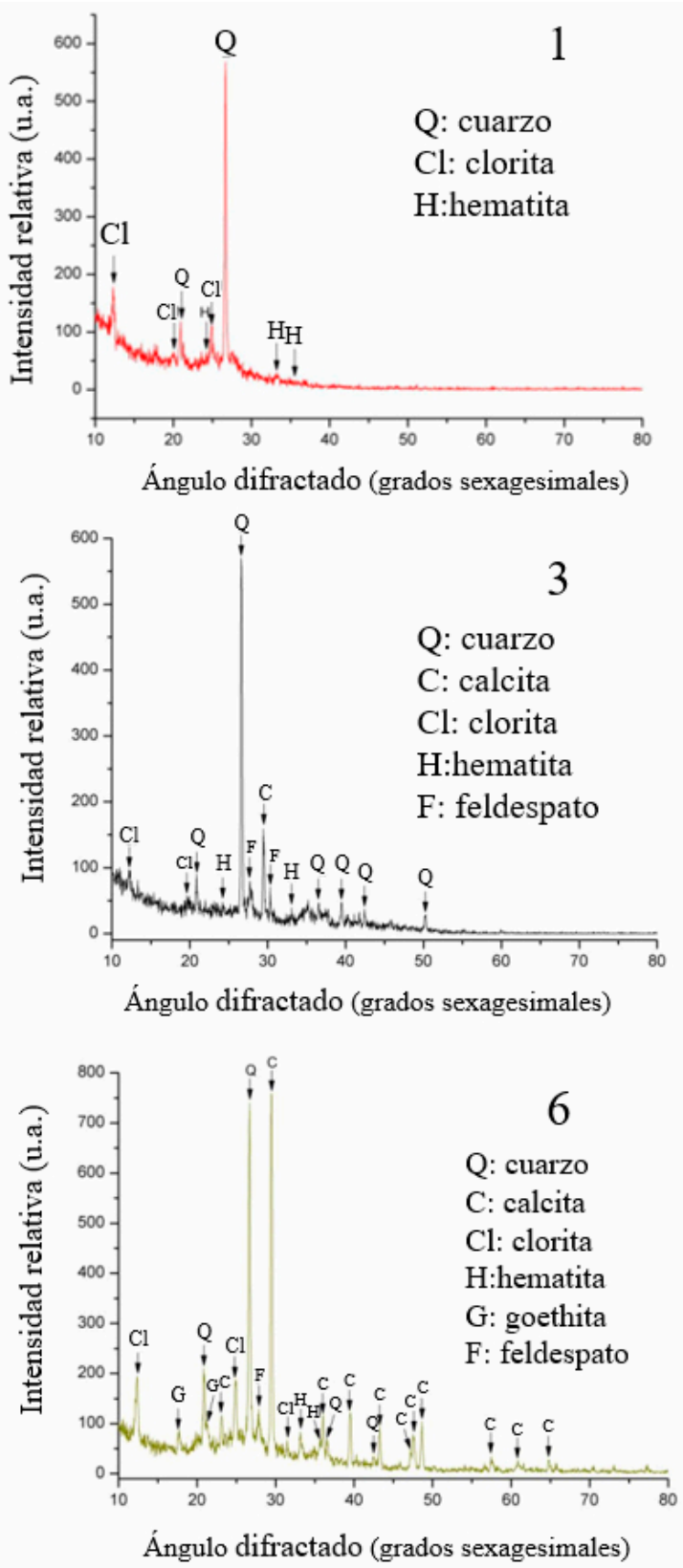

FIG. 2. Imagen de las muestras procedentes del yacimiento del Cerro Borreguero (Zalamea de la Serena), donde se señalan los puntos donde se han efectuado los análisis, así como los difractogramas.

probabilidad tanto el recipiente como los pigmentos utilizados en la decoración provienen del entorno inmediato del yacimiento. En concreto, los pigmentos rojos y amarillos se elaboraron mediante el uso de óxidos e hidróxidos de hierro (Hradil et al., 2003: 224), siendo generalmente más intensa la señal de hematita en caso del rojo y de goethita en el del amarillo. En cuanto a las piedras analizadas procedentes del sustrato geológico que afloran junto al yacimiento, se confirmó que contienen gran cantidad de óxidos rojos y amarillos de tonalidades muy similares a las de las decoraciones pintadas de la cerámica, lo que 


\begin{tabular}{|c|l|l|l|}
\hline YaCIMIENTo & MUESTRA & \multicolumn{1}{|c|}{ ZoNa DEL ANÁLISIS } & \multicolumn{1}{c|}{ CoMPUESTOS CRISTALINOS IDENTIFICADOS } \\
\hline \multirow{4}{*}{$\begin{array}{c}\text { Cerro Borreguero } \\
\text { (Zalamea de la }\end{array}$} & \multirow{4}{*}{$\begin{array}{c}\text { Ref. } 509 \\
\text { Serena, Badajoz) }\end{array}$} & 1: policromía roja & cuarzo, clorita y hematita \\
\cline { 3 - 4 } & & 2: policromía amarilla sobre rojo & cuarzo, clorita, hematita, goethita y feldespato \\
\cline { 3 - 4 } & & 4: pasta cerámica de tono rojizo & cuarzo, clorita, hematita, feldespato y calcita \\
\cline { 3 - 4 } & & 6: policromía amarilla y roja & cuarzo, clorita, hematita, goethita, feldespato y calcita \\
\hline
\end{tabular}

Fig. 3. Compuestos cristalinos identificados en los análisis efectuados en un fragmento de la cazuela del Cerro Borreguero ( $Z a$ lamea de la Serena, Badajoz).

corroboraría que la cazuela fue elaborada y pintada en su entorno inmediato (Fig. 2).

Una de las características de mayor interés de estas cerámicas es su alta vulnerabilidad debido tanto a la fragilidad de sus finísimas paredes como al hecho de que la decoración fue aplicada tras la cocción de la pieza, lo que impide que quede bien adherida a la superficie; de hecho, hay que tener un cuidado extremo para no borrar la decoración cuando se manipulan. Esta circunstancia supone que las cerámicas de este tipo fueron diseñadas para ser utilizadas de forma puntual, seguramente para rituales muy determinados; $y$, en el caso que nos ocupa, para una ceremonia relacionada concretamente con la amortización de la cabaña. Esta observación ya ha sido realizada por otros investigadores, en concreto para las cerámicas tipo 'Medellín' aparecidas en las tumbas más antiguas de la necrópolis homónima (Torres, 2008: 727). Sin embargo, como veremos más adelante, sugerimos otra interpretación que en realidad complementa esta hipótesis.

(C) Universidad de Salamanca

\section{Análisis de las cerámicas pintadas bícromas poscocción de la vertiente atlántica de la Península Ibérica}

Este tipo de cerámicas pintadas son muy comunes en el valle del Guadiana, donde además de Medellín se han localizado en el yacimiento de la Bienvenida (Ciudad Real) (Zarzalejos et al., 2012: 21) o Alarcos (Ciudad Real) (García Huerta y Morales, 2017). Pero quizá son más representativas en la Meseta Norte, de donde procede un amplio elenco de

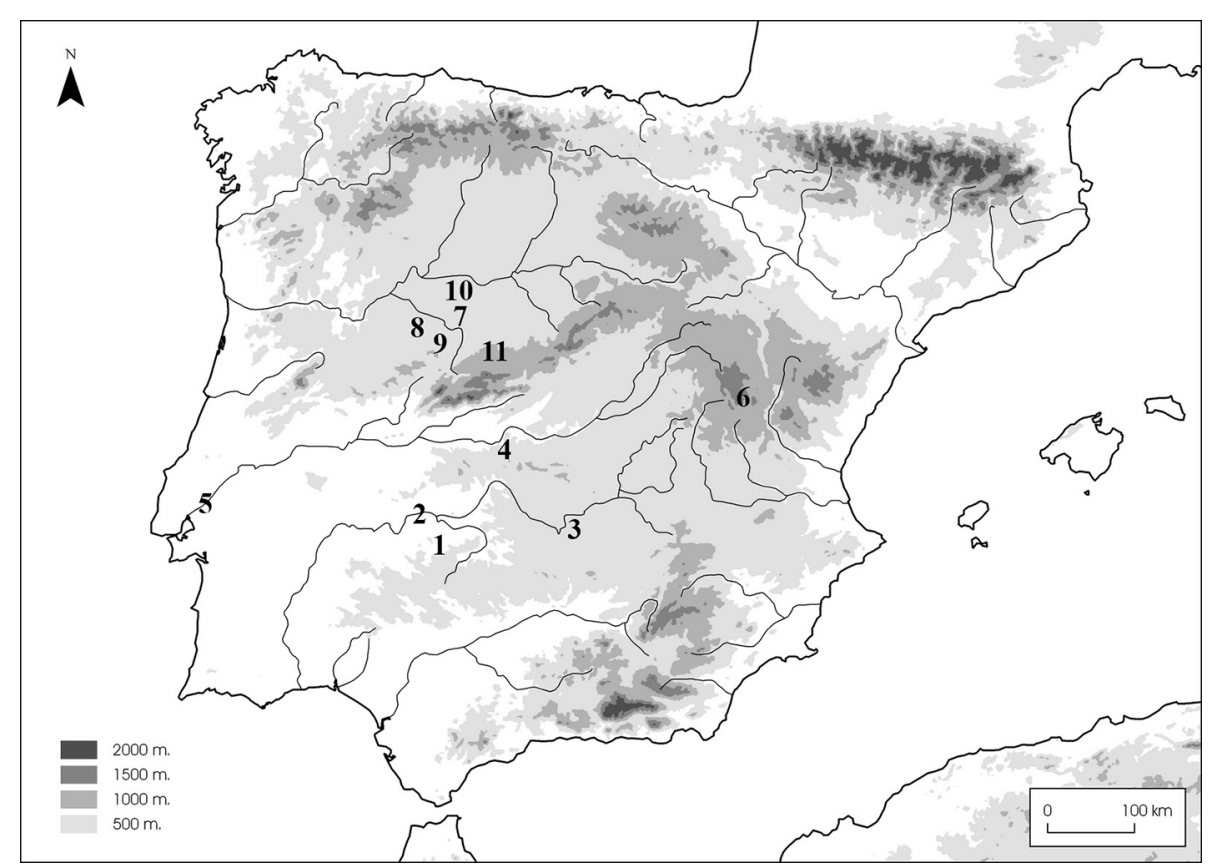

FIG. 4. Mapa de localización de los diferentes yacimientos con cerámicas pintadas poscocción analizadas en este estudio: 1. Cerro Borreguero (Zalamea de la Serena, Badajoz); 2. Necrópolis y Cerro del Castillo (Medellín, Badajoz); 3. Alarcos (Ciudad Real); 4. Casa del Carpio (Belvís de la Jara, Toledo); 5. Santarém (Portugal); 6. Sima Cabeza de la Fuente (Boniches de la Sierra, Cuenca); 7. Cerro de San Vicente (Salamanca); 8. San Martín (Ledesma, Salamanca); 9. Cerro de San Pelayo (Martinamor, Salamanca); 10. La Aldehuela (Zamora); 11. Sanchorreja (Ávila). 
cerámicas de este tipo que han sido sometidas a una exhaustiva analítica en el laboratorio del SECYR para evaluar sus concomitancias con las halladas en el Guadiana y estudiar así sus posibles analogías.

La ingente bibliografía que han generado las cerámicas pintadas poscocción pone de manifiesto la dificultad que existe a la hora de encuadrarlas en un marco cultural concreto; además, su dispersión geográfica no ha ayudado a especificar los influjos a los que pudo estar sometido un estilo que se antoja muy homogéneo, por lo que las propuestas sobre su origen son también diversas. Tal vez el problema principal radique en que hemos querido meter en el mismo saco a todas las cerámicas pintadas poscocción, cuando en realidad se pueden identificar varios tipos que a nuestro modo de ver difieren entre sí, lo que no es óbice para que en ocasiones aparezcan en un mismo yacimiento de forma coetánea. Este es el caso de las cerámicas tipo 'Carambolo', en ocasiones asociadas a las de estilo 'Medellín', con las que poco tienen que ver tanto técnica como estéticamente (Casado, 2015). Lo mismo ocurre con las cerámicas pintadas del sureste peninsular, alejadas de los tipos decorativos y de las manufacturas de las cerámicas que aquí queremos tratar. También se han descartado las cerámicas pintadas del valle del Ebro porque a pesar de que algunos investigadores las han estudiado conjuntamente con las de la Meseta, el Levante o el Sureste peninsular (González Prats, 1983: 121), son sensiblemente diferentes. En definitiva, no existe consenso entre los distintos investigadores a la hora de diseñar una tipología de estas cerámicas, que han sido englobadas bajo el epígrafe de pintadas del Bronce Final/I Edad del Hierro (Blasco, 1981) 'pintadas tartésicas' (Ruiz Mata, 1986) o pintadas geométricas del Bronce Final/Hierro (Werner, 1990). Sin embargo, no se hacen distinciones entre las formas que presentan ni entre la técnica de elaboración, incluyendo a veces en el mismo fenómeno las elaboradas a mano y las realizadas a torno.

Dada esta heterogeneidad, hemos creído oportuno centrarnos solo en las cerámicas pintadas bícromas que tan presentes están en la vertiente atlántica de la Península Ibérica y que presentan como característica común la elaboración a mano, la cocción reductora, las paredes finas y las formas semejantes a las empleadas en el Bronce Final; además, por lo general, estas cerámicas están alisadas o bruñidas y pintadas básicamente con óxidos rojos y amarillos, si bien también se han documentado ejemplares con tonalidades blancas e incluso azuladas, caso de algunas procedentes de Medellín. Por último, todas ellas participan de una cronología muy similar que se establece, según las zonas, en el momento de transición del Bronce Final a la I Edad del Hierro, respaldadas por varias cronologías absolutas como queda recogido en el presente trabajo.

Una vez analizado el vaso del Cerro Borreguero, y dados los interesantes resultados obtenidos, creímos que era oportuno abrir dentro de nuestro proyecto de investigación una vía que sirviera para armonizar y buscar concomitancias técnicas a través de los análisis de los ejemplares más significativos que, su vez, nos sirviera para emprender un estudio sobre las relaciones entre las diferentes zonas donde se produjo este fenómeno de las cerámicas pintadas poscocción. De este modo, se realizó una selección de los yacimientos más representativos donde se habían documentado cerámicas similares a la de Cerro Borreguero y que coincidían con el área de la Meseta Norte, el Guadiana medio y alto y el valle del Tajo (Fig. 4). Así, de la Meseta Norte se recogieron muestras para analizar del Cerro San Pelayo, de la plaza de San Martín de Ledesma y del Cerro de San Vicente (Salamanca); de La Aldehuela (Zamora); y de Sanchorreja (Ávila). De la Meseta Sur se analizaron muestras de la tumba de El Carpio de Belvís de la Jara (Toledo) y de Sima de Cabeza de la Fuente de Boniches de la Sierra (Cuenca). De la cuenca del Guadiana se seleccionaron fragmentos del poblado y la necrópolis de Medellín (Badajoz) y del yacimiento de Alarcos (Ciudad Real), enclaves que se han completado con los análisis que el Departamento de Química Agrícola, Geología y Geoquímica de la UAM había realizado sobre un lote de piezas procedentes del yacimiento de Sisapo (Ciudad Real). Por último, el valle del Tajo se ha completado con los análisis efectuados sobre un 
fragmento procedente del yacimiento de Santarém (Portugal). No pudimos contar, sin embargo, con muestras de algunos yacimientos de la Comunidad de Madrid por la complicada burocracia que suponía, ni con el magnífico ejemplar de Portaceli, hallado en el entorno del castillo de Medellín (Jiménez y Haba, 1995) pues en su momento no pudimos localizarlo en el Museo de Badajoz².

También optamos por no realizar análisis de los tipos que aparecen en contextos con cronologías más recientes o que creemos que corresponden a otros impulsos culturales, caso de los ejemplares que se encuentran en las áreas del Ebro, Levante y sureste peninsular, pues, a pesar de que presentan una decoración pintada con colores similares a los que aquí estudiamos, su distribución geográfica, sus formas, su composición decorativa y sus cronologías se alejan de los ejemplos aquí analizados. Así, las cerámicas pintadas procedentes de Cortes de Navarra, que sirvieron de punto de referencia por ser el primer sitio donde se documentaron y que abrieron la puerta a la influencia hallstáttica de estas cerámicas pintadas peninsulares (Maluquer de Motes, 1954), solo se documentan en el yacimiento en el Nivel P II b, fechado a partir del s. vII, perdurando hasta mediados del vi a. C. (Maluquer de Motes, 1954: 114), pero, además, con una técnica de elaboración muy diferente. Este tipo de cerámica es común a otros yacimientos del valle del Ebro y la zona oriental de la Meseta Norte, caso de los ejemplares de la necrópolis de la Edad del Hierro de Molina de Aragón (Cerdeño, 1983). También hemos prescindido de los ejemplares del Poblado ir de la Plaza del Castillo de Cuéllar por tratarse de grandes vasos con decoración bícroma

2 Queremos expresar nuestro agradecimientos a los directores de los museos implicados en este trabajo de investigación por la ayuda y facilidades que nos ofrecieron para aligerar nuestro trabajo de la carga burocrática que conlleva este tipo de analíticas. Así mismo, agradecer a A. M. Arruda por hacernos llegar un fragmento procedente de las excavaciones de Santarém, a R. García Huerta su confianza por facilitarnos muestras de las cerámicas de Alarcos y a M. Zarzalejos y G. Esteban por proporcionarnos los datos de los análisis de Sisapo; pero también por poner a nuestra disposición sus textos inéditos para enriquecer este trabajo. sobre superficies claras que se alejan técnica y cronológicamente del resto de ejemplares que aquí analizamos y que además se fechan en torno al s. $\mathrm{v}$ a. C. (Barrio, 1993: 190; 2002). Motivos similares nos han llevado a excluir los vasos pintados de la magnífica necrópolis de Las Madrigueras (Almagro-Gorbea, 1969), uno de los primeros yacimientos donde se documentaron este tipo de cerámicas polícromas. De las 65 tumbas de la necrópolis, las cerámicas pintadas con tonos rojos, blancos y amarillos, y siempre realizadas a mano, aparecen en las Tumbas XXIII, XLII, L y LIV, bien fechadas en los ss. vi y v a. C. (Almagro-Gorbea, 1969: 114), por lo que una vez más parecen responder a impulsos más modernos relacionados con el sur peninsular. Por último, las cerámicas bícromas poscocción del sureste peninsular, y en concreto el grupo específico denominado tipo 'Real' (Molina, 1978: 174), responden a un movimiento que parece tener una relación más directa con el valle del Guadalquivir desde los inicios de la I Edad del Hierro, si no antes (Carrasco et al., 1986: 227). Por ello, hemos centrado nuestro estudio en las cerámicas a mano bícromas -rojo y amarillo fundamentalmente- pintadas tras la cocción de la pieza y distribuidas por la vertiente atlántica, a excepción del ejemplar de la Sima Cabeza de la Fuente (Cuenca), entre las que existe una innegable homogeneidad, si bien con las singularidades propias de cada zona.

Los fragmentos seleccionados fueron analizados también en el SECYR de la UAM con el objetivo de identificar los componentes de sus pastas y el de los pigmentos de su policromía. Al igual que sobre el vaso del Cerro Borreguero, se realizaron análisis de difracción de Rayos x policristal para así configurar una tabla homogénea de resultados. Como uno de los objetivos principales del estudio era la identificación de los minerales que componen las policromías, se seleccionaron zonas de análisis que presentan diferentes coloraciones con el fin de ofrecer los mejores datos de la difracción (Beck et al., 2014: 461). Así mismo, como es habitual en estas analíticas, se realizó una microscopía electrónica de barrido -MEB- para caracterizar morfológica, estructural y composicionalmente la superficie de las cerámicas, 

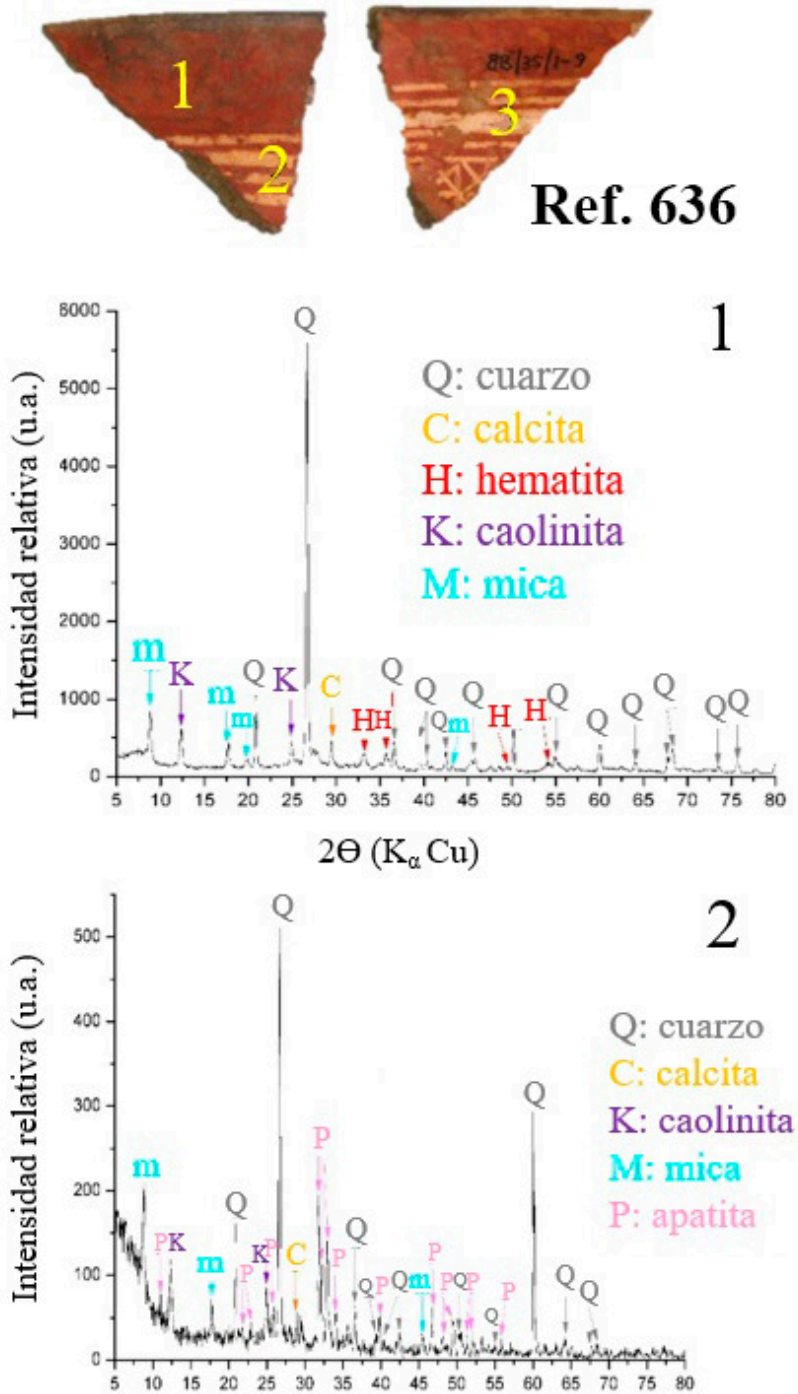

$2 \Theta\left(\mathrm{K}_{\alpha} \mathrm{Cu}\right)$

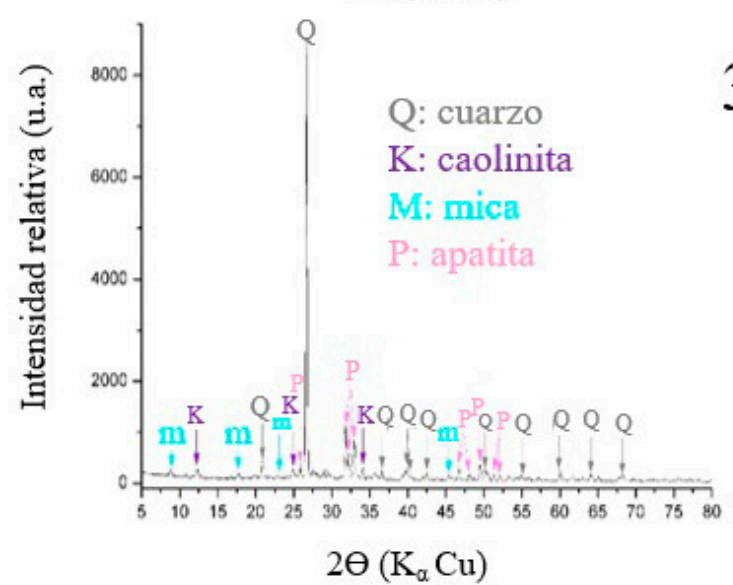

(c) Universidad de Salamanca

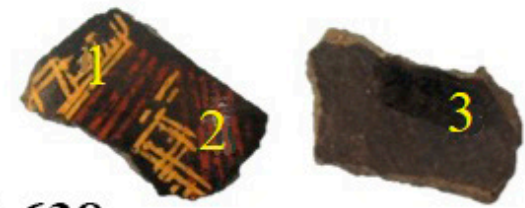

Ref. 638
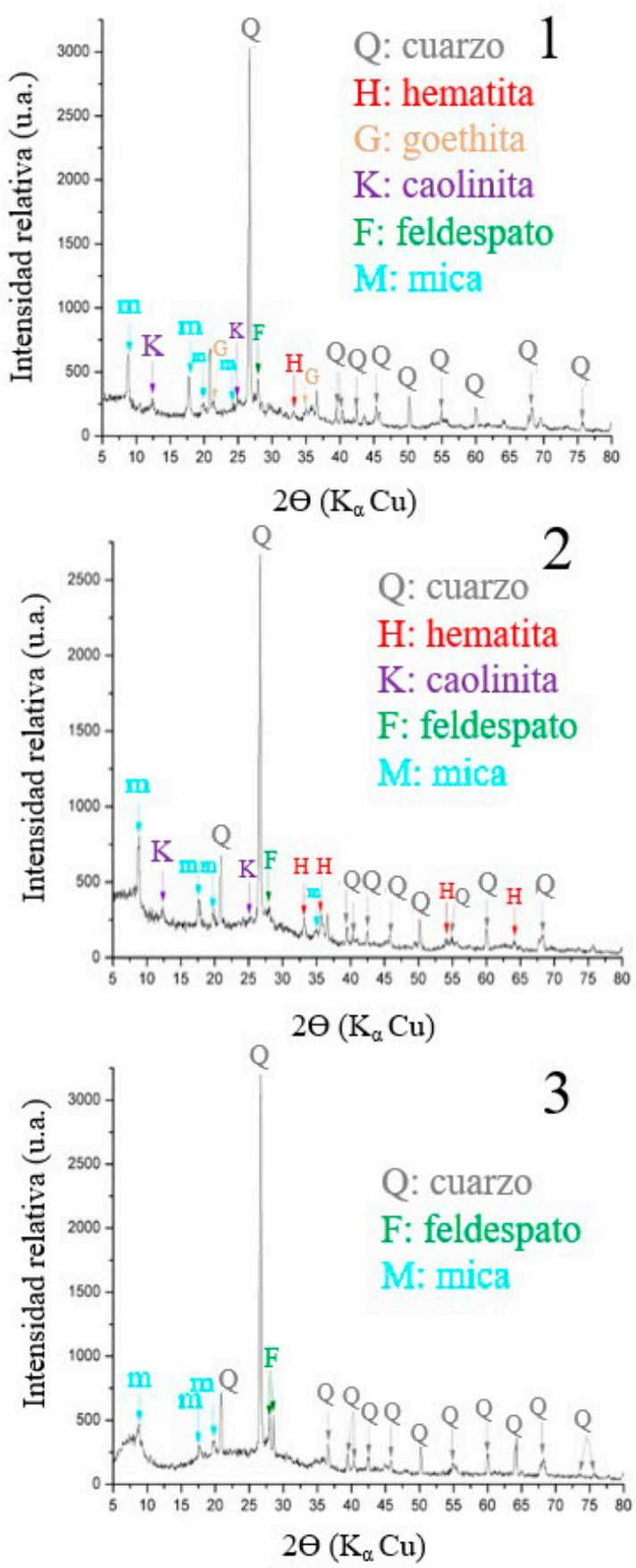

Zephyrus, LXXXII, julio-diciembre 2018, 119-148 

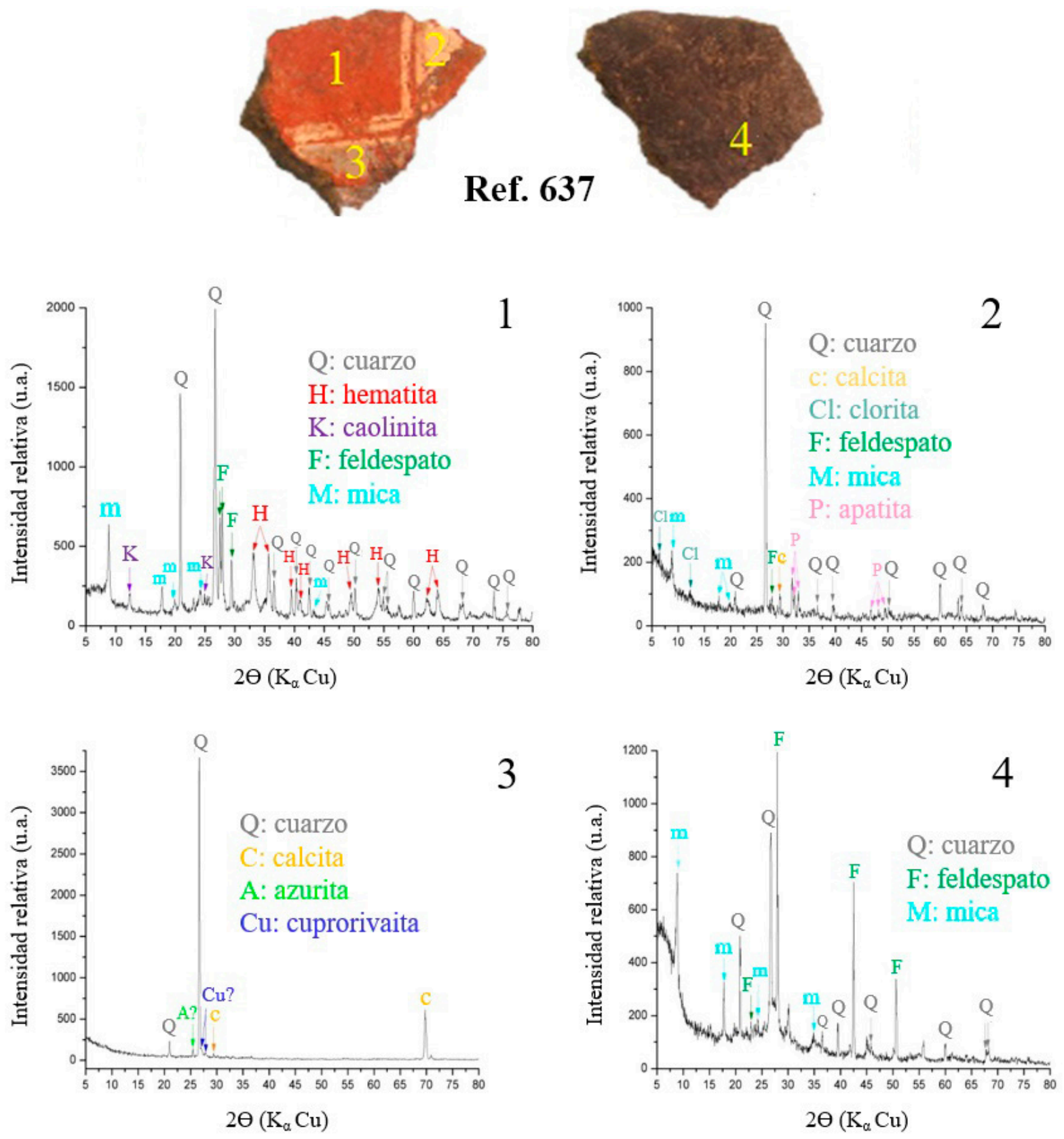

FIG. 5. Muestras procedentes del yacimiento de La Aldehuela (Zamora) donde se señalan los puntos donde se han efectuado los análisis y los difractogramas resultantes.

complementada con un análisis por energía dispersiva de Rayos $\mathrm{X}-\mathrm{MEB} / \mathrm{EDX}^{3}$-, que proporciona un análisis cualitativo y a veces incluso cuantitativo de la composición elemental de la muestra.

El estudio de las pastas ha permitido comprobar que todos los fragmentos analizados están compuestos por arcillas micáceas con un alto contenido fundamentalmente en cuarzo, pero también con presencia de feldespato y moscovita como desgrasante; algunos, como los tres ejemplares de El Carpio, presentan además rastros de clorita. Por lo tanto, la regularidad en la elaboración de estos ejemplares es la tónica general. 

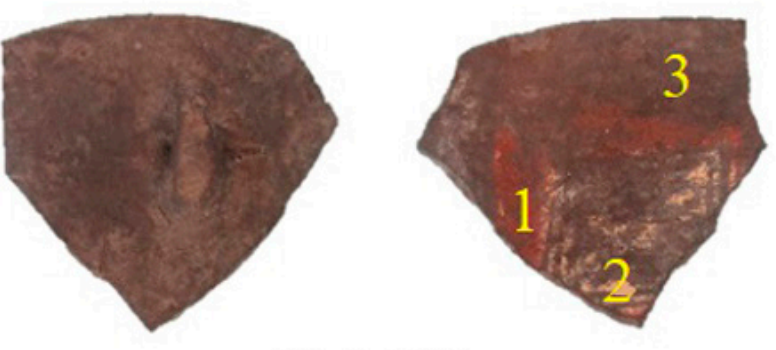

Ref. 748

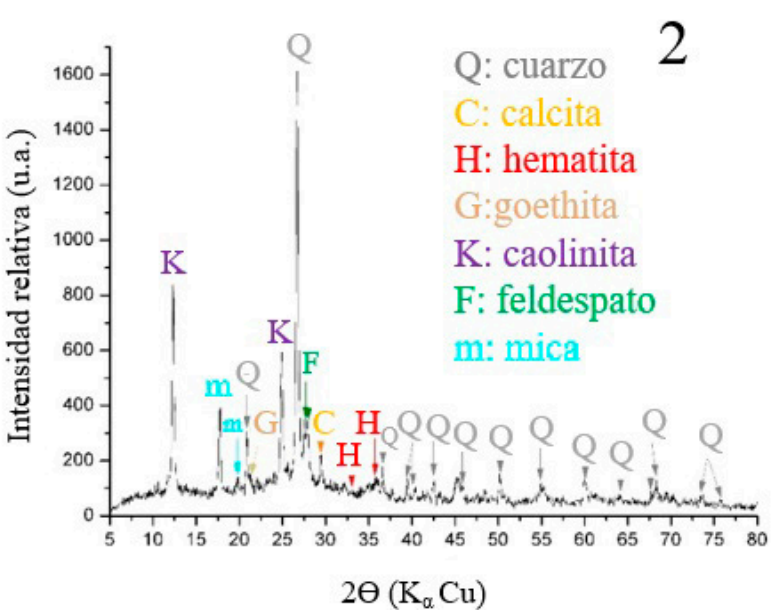

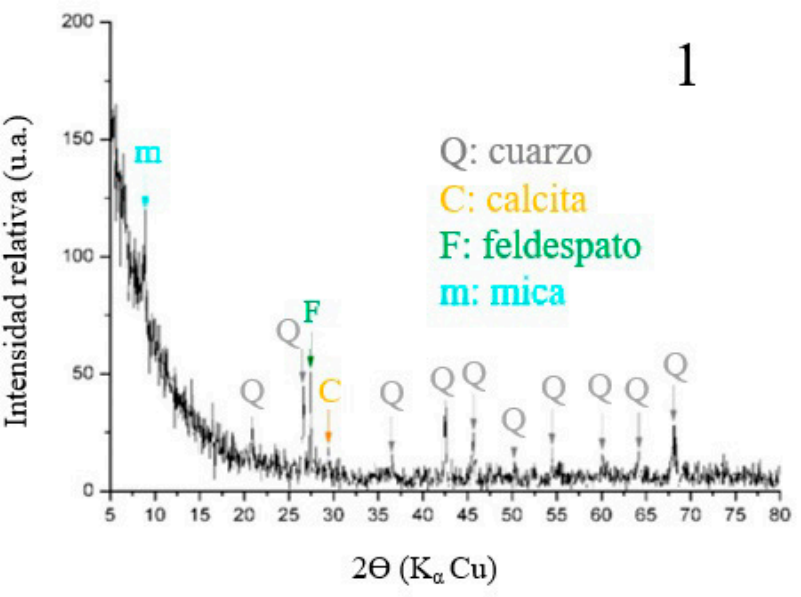

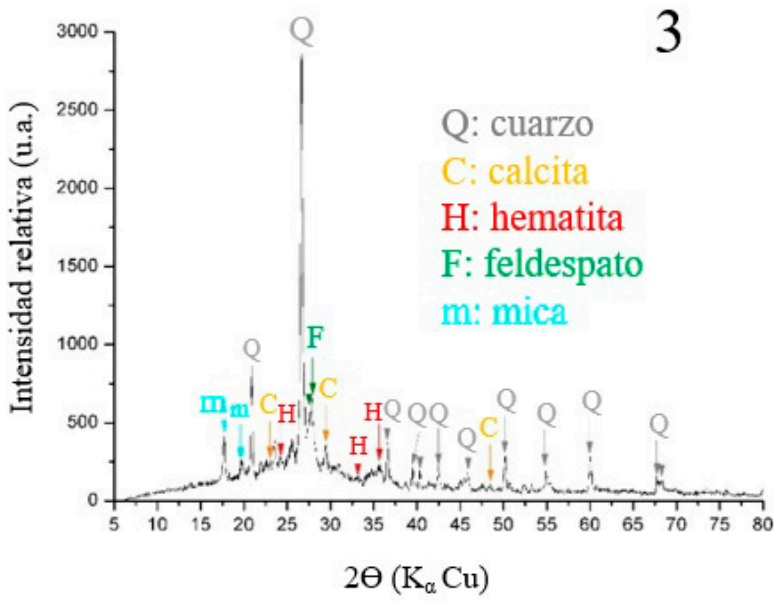

FIG. 6. Muestra procedente del yacimiento de Sanchorreja (Ávila) donde se señalan los puntos donde se han efectuado los análisis y los difractogramas resultantes.

Por su parte, de los difractogramas realizados en los pigmentos utilizados para decorar las cerámicas también se deduce cierta homogeneidad, pero con señaladas diferencias en algunas zonas. En general se utilizaron pigmentos inorgánicos, ocres naturales a base de óxidos o hidróxidos de hierro, hematita y goethita principalmente, tanto para los rojos como para los amarillos. Para los blancos, escasamente representativos en estos conjuntos, se emplearon la calcita y la dolomita, caso de El Carpio. En cuanto a los tonos azules que se detectan en los ejemplares de Medellín y Cerro de San Vicente, se realizaron a base de silicato de cobre y calcio. Pero lo que llama la atención es la uniformidad en la presencia de la caolinita como probable aglutinante y fijador de la pintura (Judson, 1959: 708), pues se documenta en todos los ejemplares de la Meseta Norte: La Aldehuela (Fig. 5), en todos los fragmentos, y en Sanchorreja (Fig. 6); en la zona del Guadiana, caso de los ejemplares de Medellín (Fig. 7) y de Alarcos (Fig. 8); y, por último, en el ejemplar de la Sima de Cabeza de la Fuente del museo de Cuenca (Fig. 9). Tan solo los ejemplares de El Carpio (Fig. 10) y Santarém (Fig. 11), ambos yacimientos en el valle del Tajo, escapan de esta composición al fijar la pintura mediante dolomita.

Pero hay otra característica muy significativa que solo se detecta en los ejemplares de una zona geográfica muy acotada. En efecto, en los fragmentos analizados de la plaza de San Martín de Ledesma (Fig. 12), del Cerro de San Pelayo (Fig. 13) y del Cerro de San Vicente (Fig. 14), todos de la provincia 


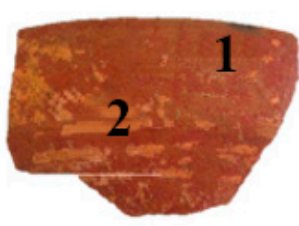

\section{Ref. 643}
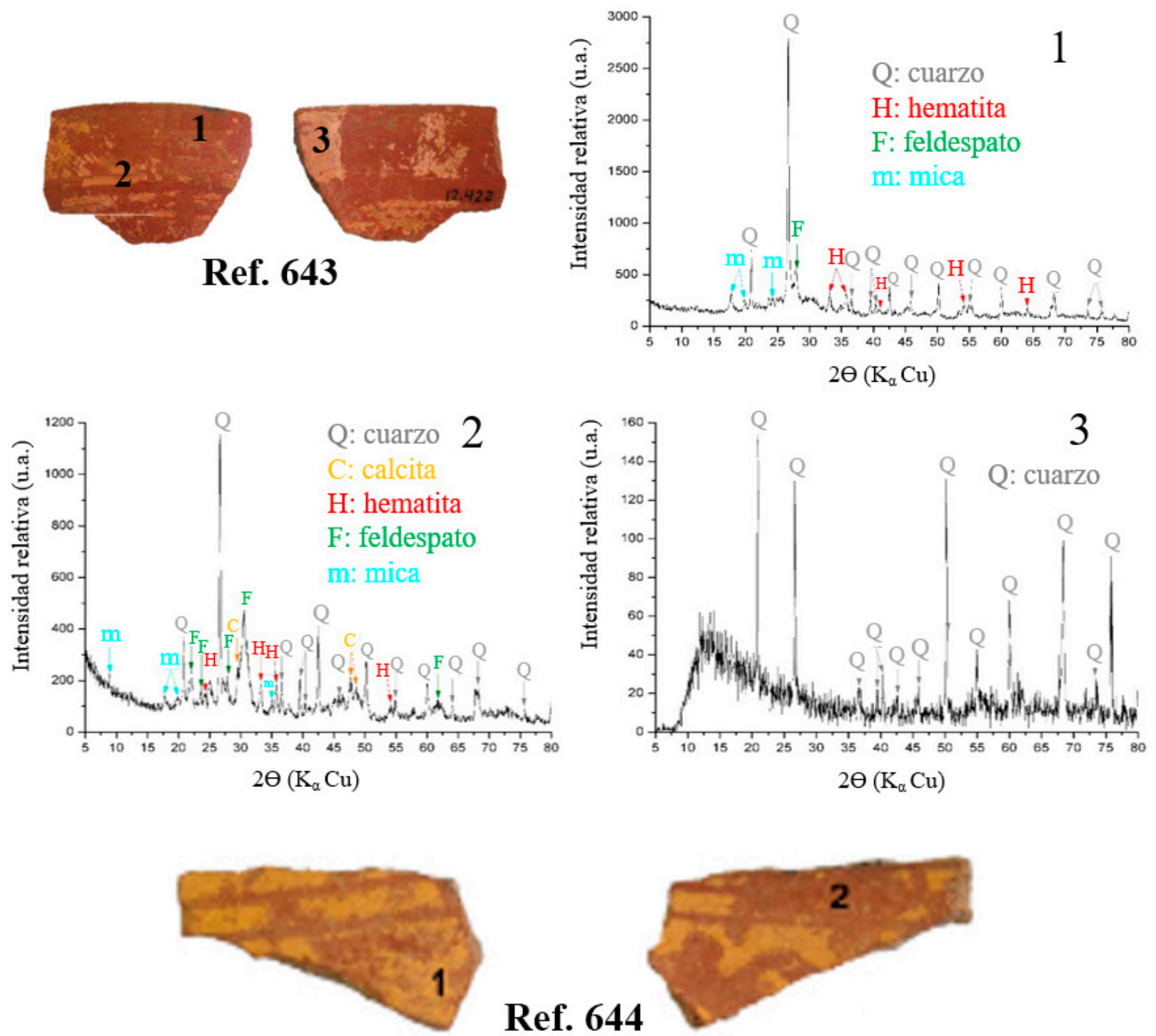

\section{Ref. 644}
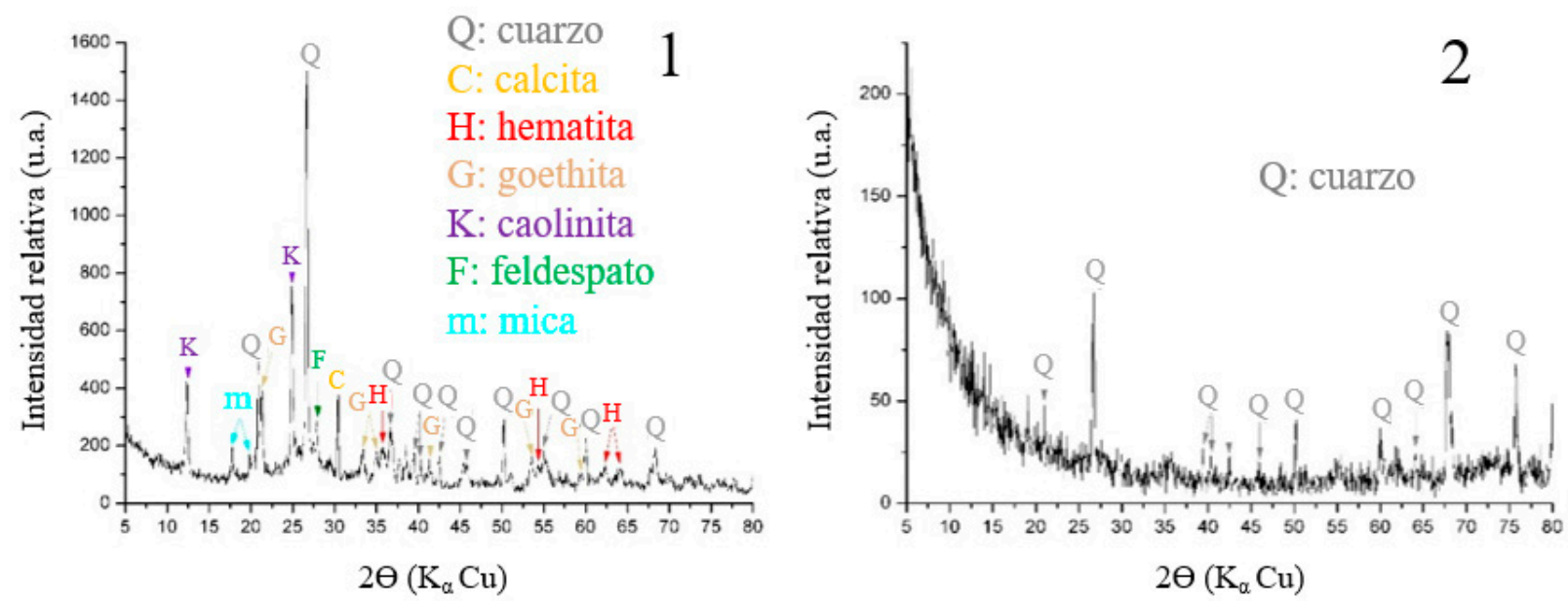


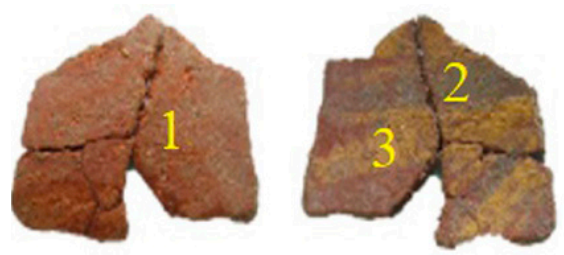

Ref. 653
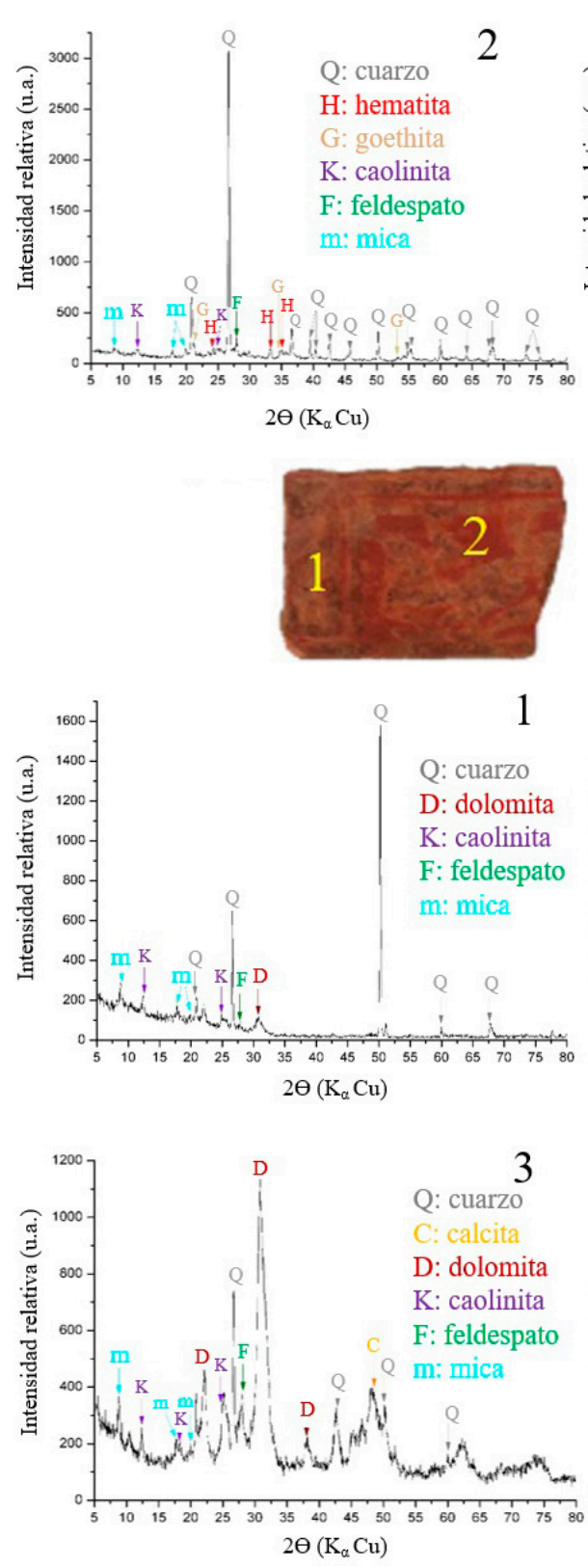

$2 \Theta\left(\mathrm{K}_{\alpha} \mathrm{Cu}\right)$
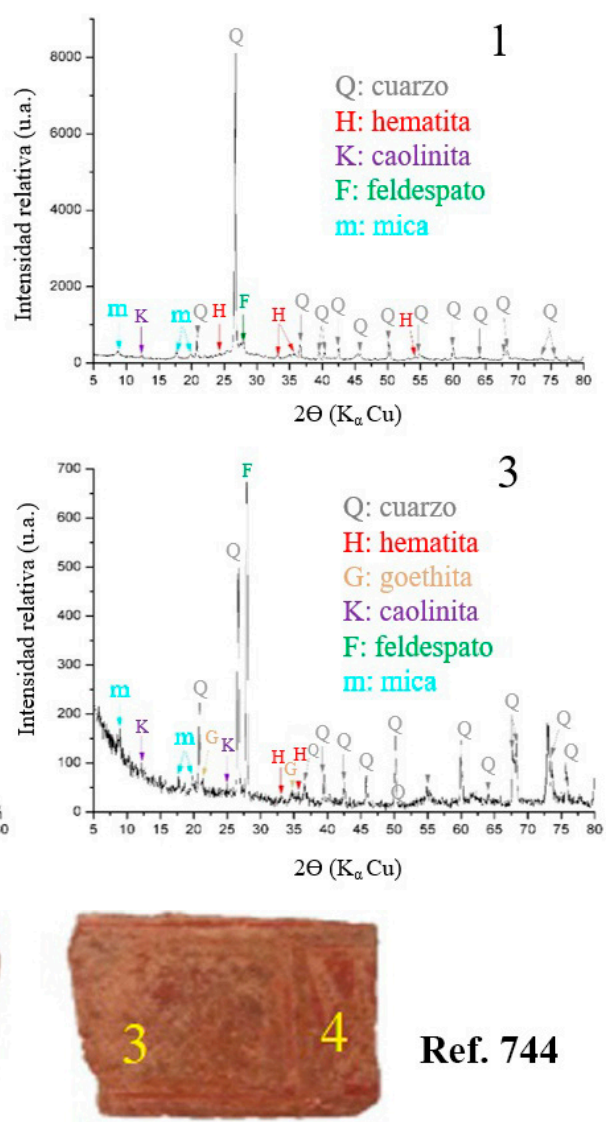

Ref. 744
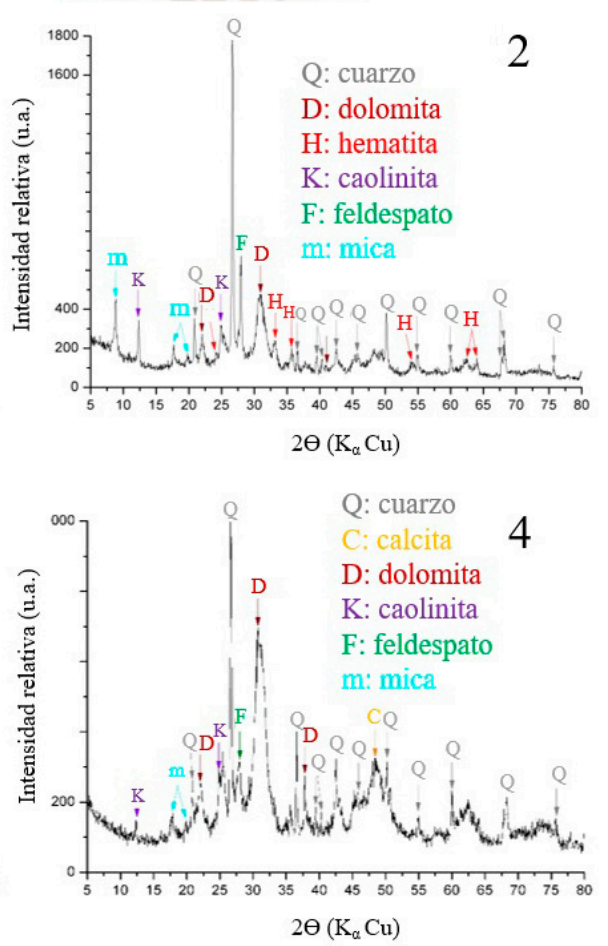

de Salamanca, y en el ejemplar de La Aldehuela de Zamora, se han detectado en las policromías más claras, blanco y amarillo, caolinita junto a apatita biogénica, resultado de haberse calcinado un hueso blanco para intensificar los colores. La apatita podría tener un origen inorgánico, ya que es común su cristalización a partir de un magma silíceo o carbonítico o su aparición en zonas de mineralización asociado a granitos; o un origen biogénico, dado que es el principal componente inorgánico de los huesos o dientes (Eastaugh et al., 2004: 20-21). En algunos trabajos ya se ha apuntado en esta última dirección, advirtiendo el empleo del hueso blanco molido como pigmento blanco sobre cerámicas (Kakoulli, 2002: 64; Baldini et al., 2005: 97-99; Marte et al., 2012: 59-60; Frère et al., 2016: 45-55). En otros, incluso, se abre la puerta a su utilización

FIG. 7. Muestras procedentes tanto de la necrópolis como del Cerro del Castillo de Medellin (Badajoz) donde se señalan los puntos donde se han efectuado los análisis $y$ los difractogramas resultantes. 
FIG. 8. Muestras procedentes del yacimiento de Alarcos (Ciudad Real) donde se señalan los puntos donde se han efectuado los análisis $y$ los difractogramas resultantes.

como carga de otros pigmentos (Swann et al., 1999: 571-573) o como aglutinante, debido a su contenido en tuétano (Álvarez, 2012: 26). Una singularidad sin duda de importancia para discriminar las técnicas decorativas de estos vasos.

La primera conclusión de toda esta amplia y completa batería de análisis es que, como ya sabíamos, todas las decoraciones pintadas se hicieron una vez que la cerámica, siempre elaborada a mano, estaba ya cocida; sin embargo, y en contra de lo que hasta ahora se pensaba, la mayor parte de las cerámicas presentan un esmerado pulido, pero, sobre todo, un bruñido previo. Es el caso de los ejemplares de El Carpio (Pereira, 1989: 400), Alarcos (García Huerta y Fernández Rodríguez, 2000: 56), La Bienvenida ${ }^{3}$, Cerro San Pelayo (Benet, 1990: 84), La Aldehuela (Santos, 1990: 226), Sima Cabeza de la Fuente (Martínez Navarrete y Pérez de la Sierra, 1980: 75) o Portaceli (Jiménez y Haba, 1995: 237). También sobre una superficie bruñida se

3 Esteban, G. (1995): Cerámicas pintadas de Sisapo (La Bienvenida, Almodóvar del Campo, Ciudad Real), p. 95. Memoria de Licenciatura inédita presentada en 1995 en la Univ. Autónoma de Madrid.

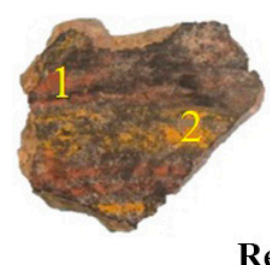

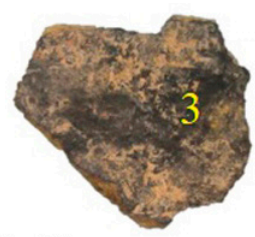

Ref. 640

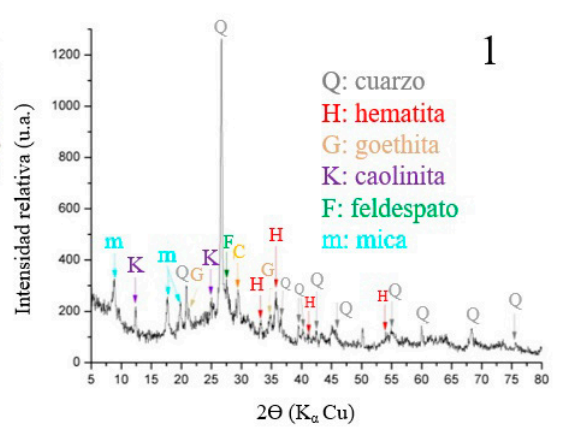

2

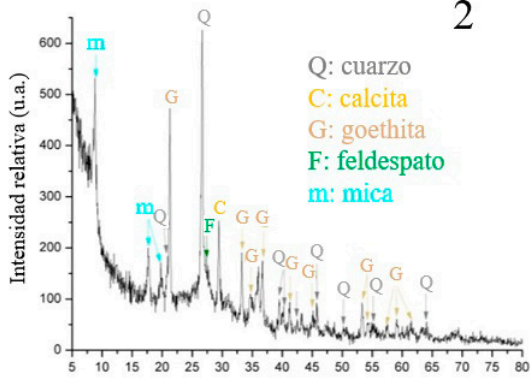

$2 \Theta\left(\mathrm{K}_{\alpha} \mathrm{Cu}\right)$

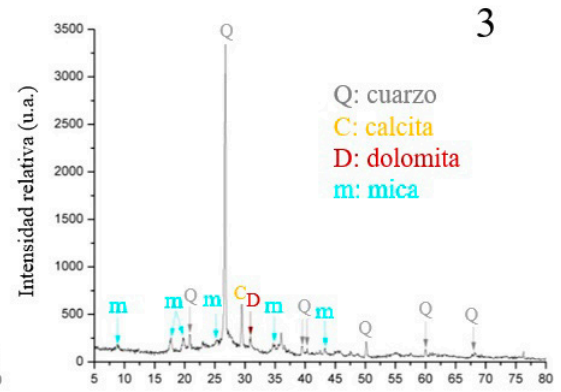

$2 \Theta\left(\mathrm{K}_{\alpha} \mathrm{Cu}\right)$

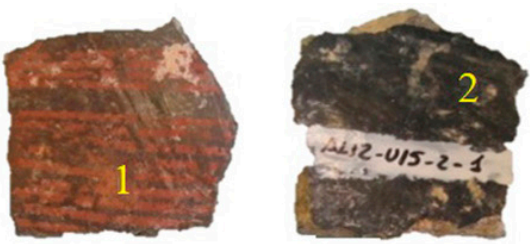

Ref. 641
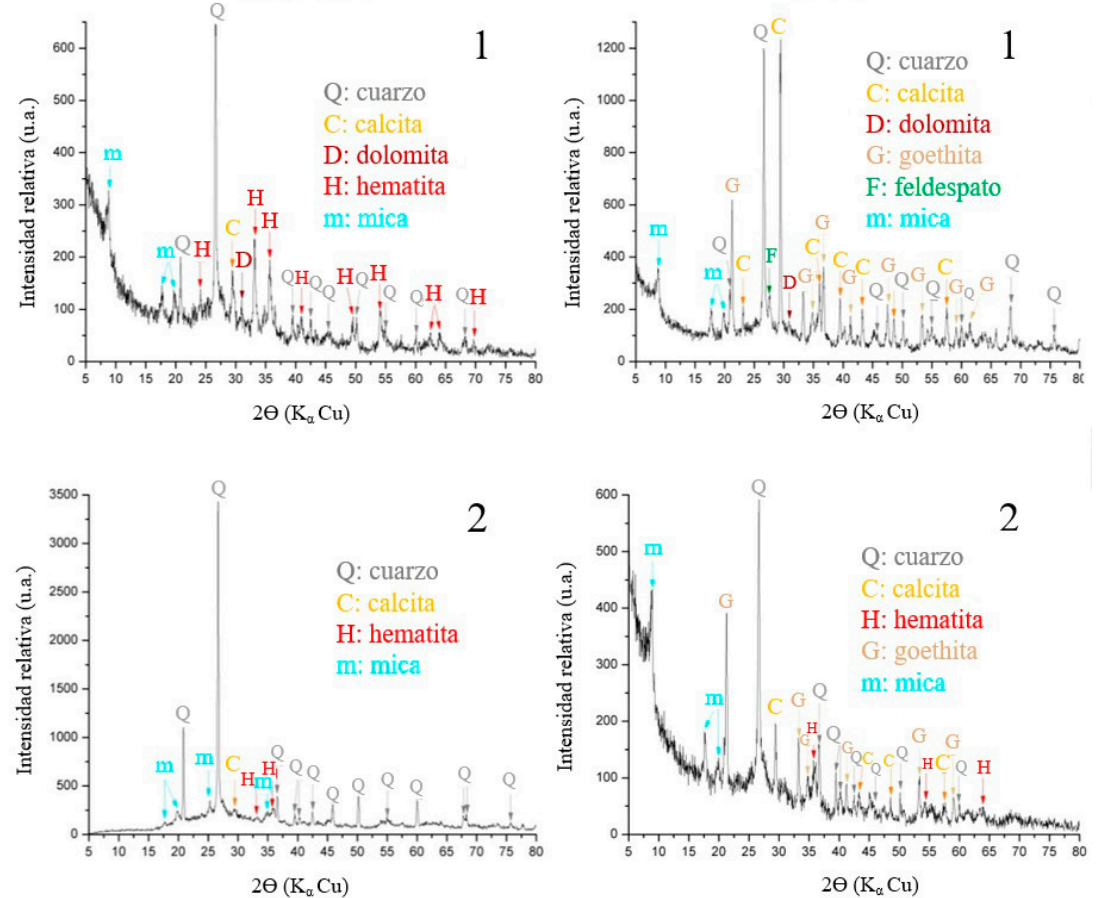

$2 \Theta\left(\mathrm{K}_{\alpha} \mathrm{Cu}\right)$ 

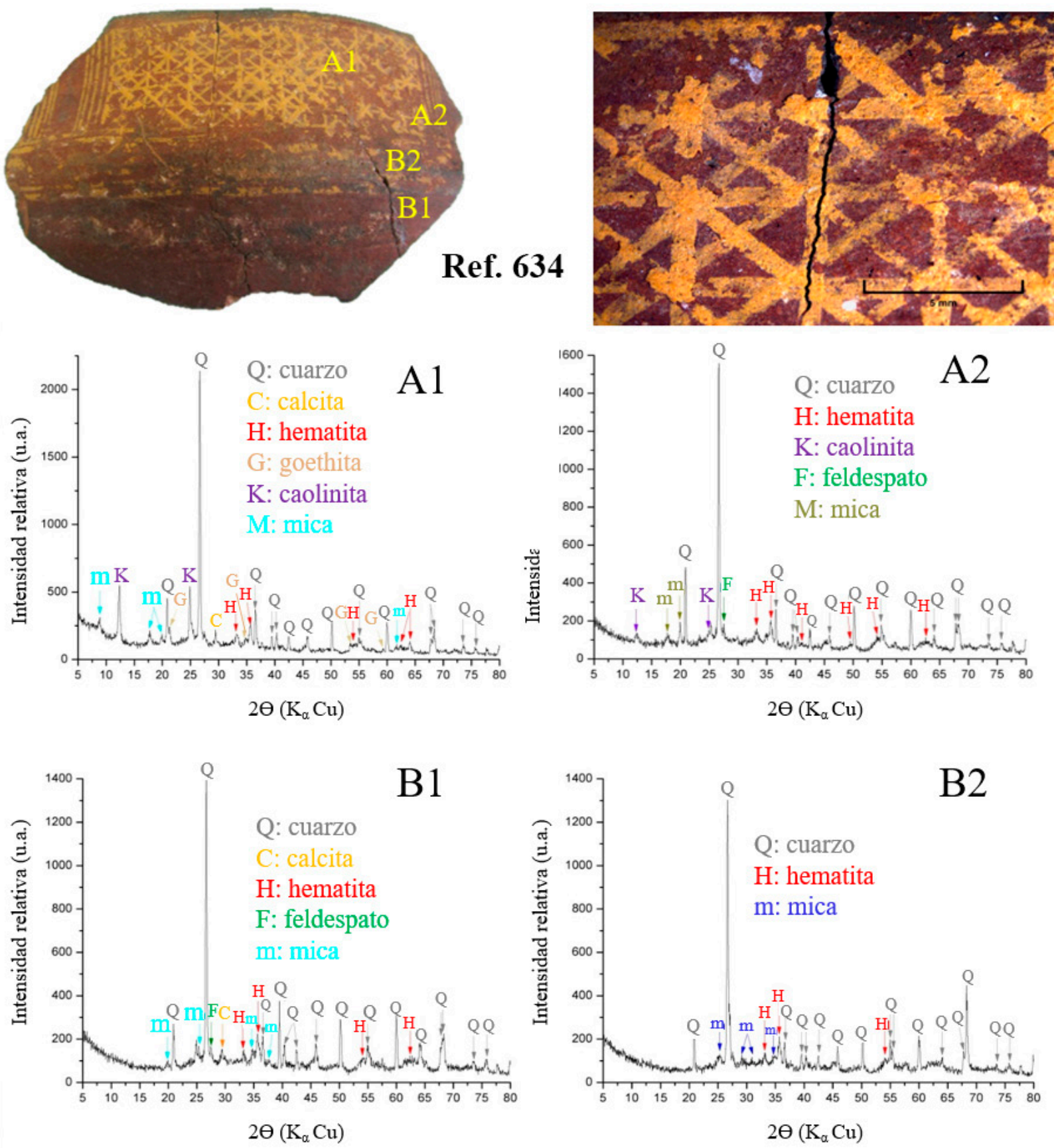

Fig. 9. Muestra procedente del yacimiento de Sima de Cabeza de la Fuente (Cuenca) donde se señalan los puntos donde se han efectuado los análisis y los difractogramas resultantes.

pintó el fragmento de Manzanares (Valiente, 1973: 335), similar a los que aquí analizamos, o el de Sanchorreja, acerca de los cuales se indica que la aplicación de la pintura bícroma se realiza "tras depurar de manera significativa la superficie de los recipientes” (González-Tablas y Domínguez, 1995: 139). Por último, con respecto a los fragmentos procedentes del poblado de Medellín, se describen como 


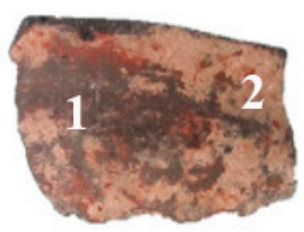

Ref.745
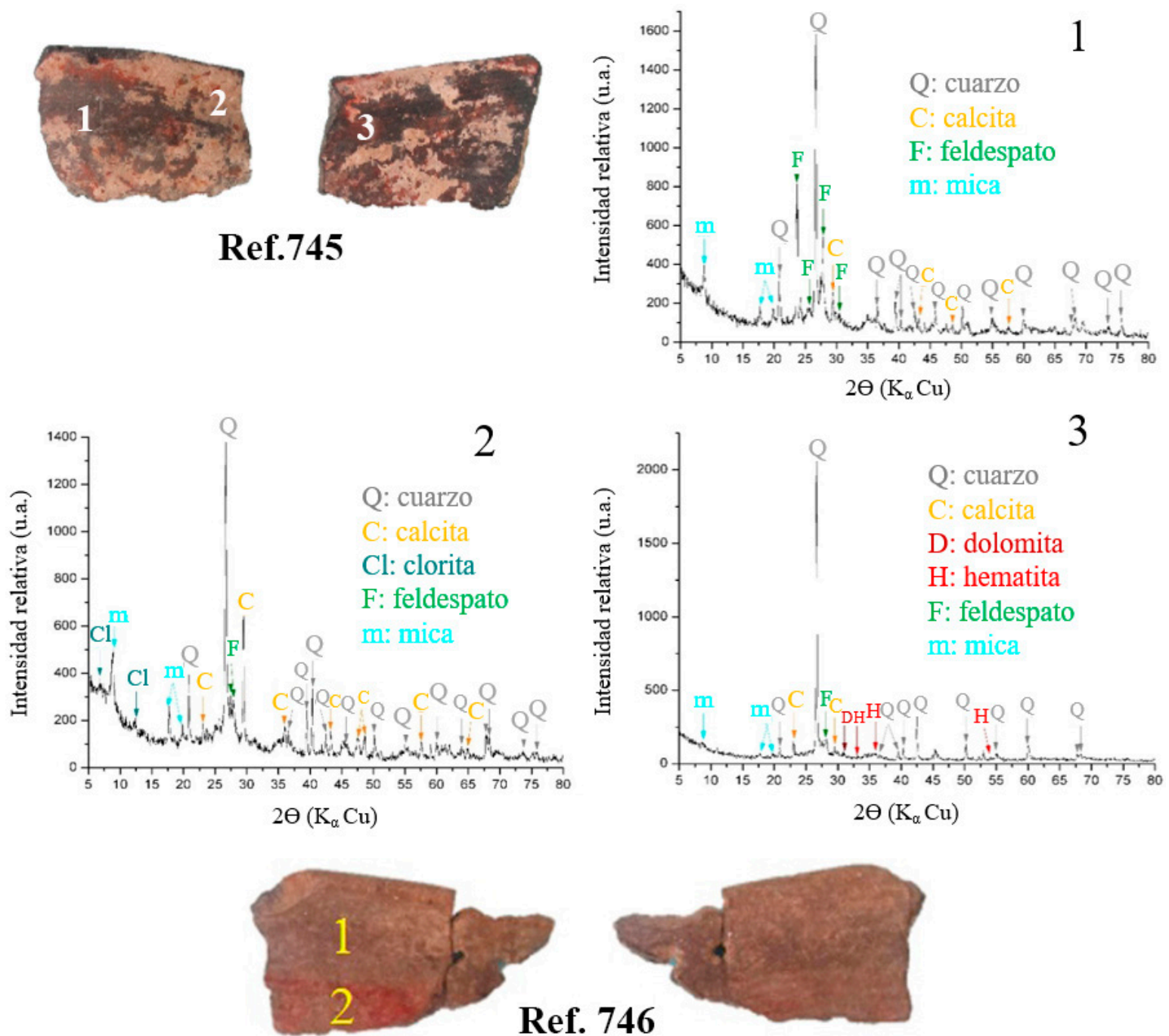

Ref. 746
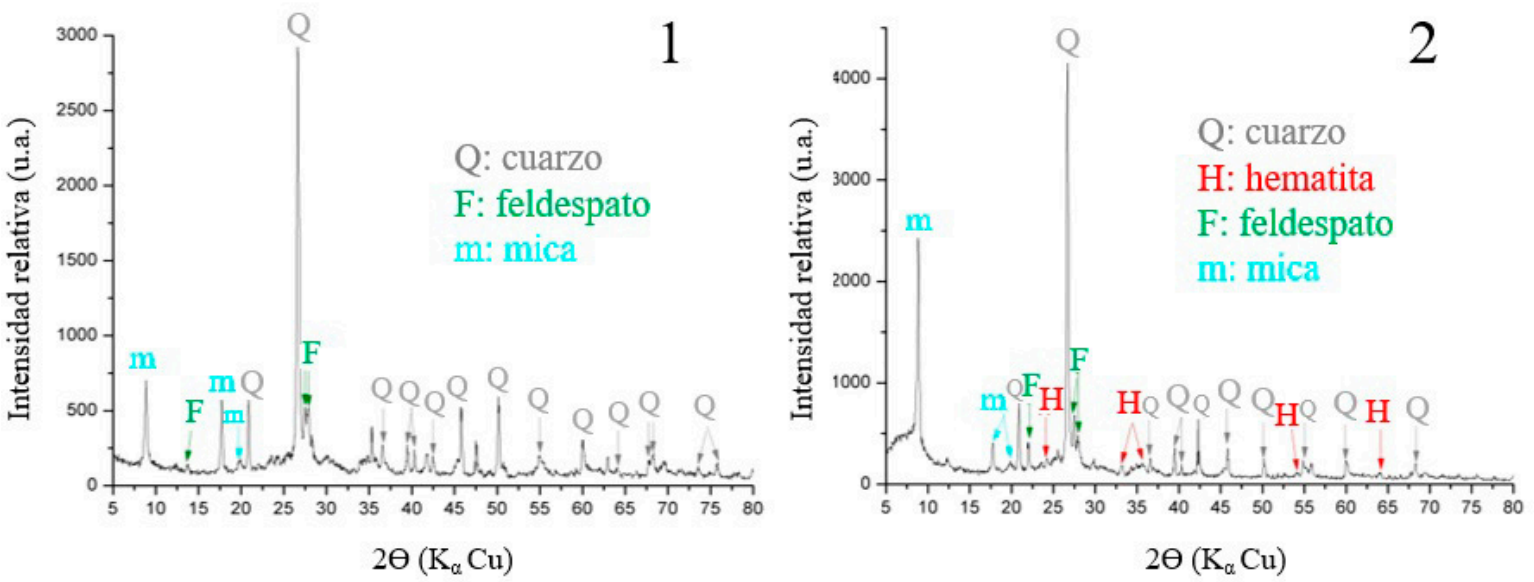

(C) Universidad de Salamanca 
Ref. 747

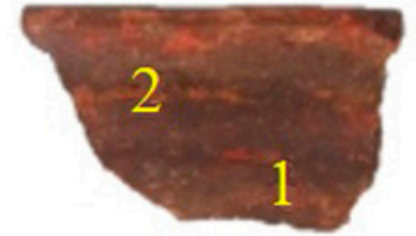

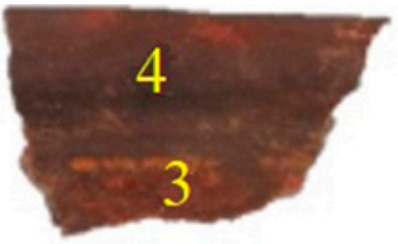
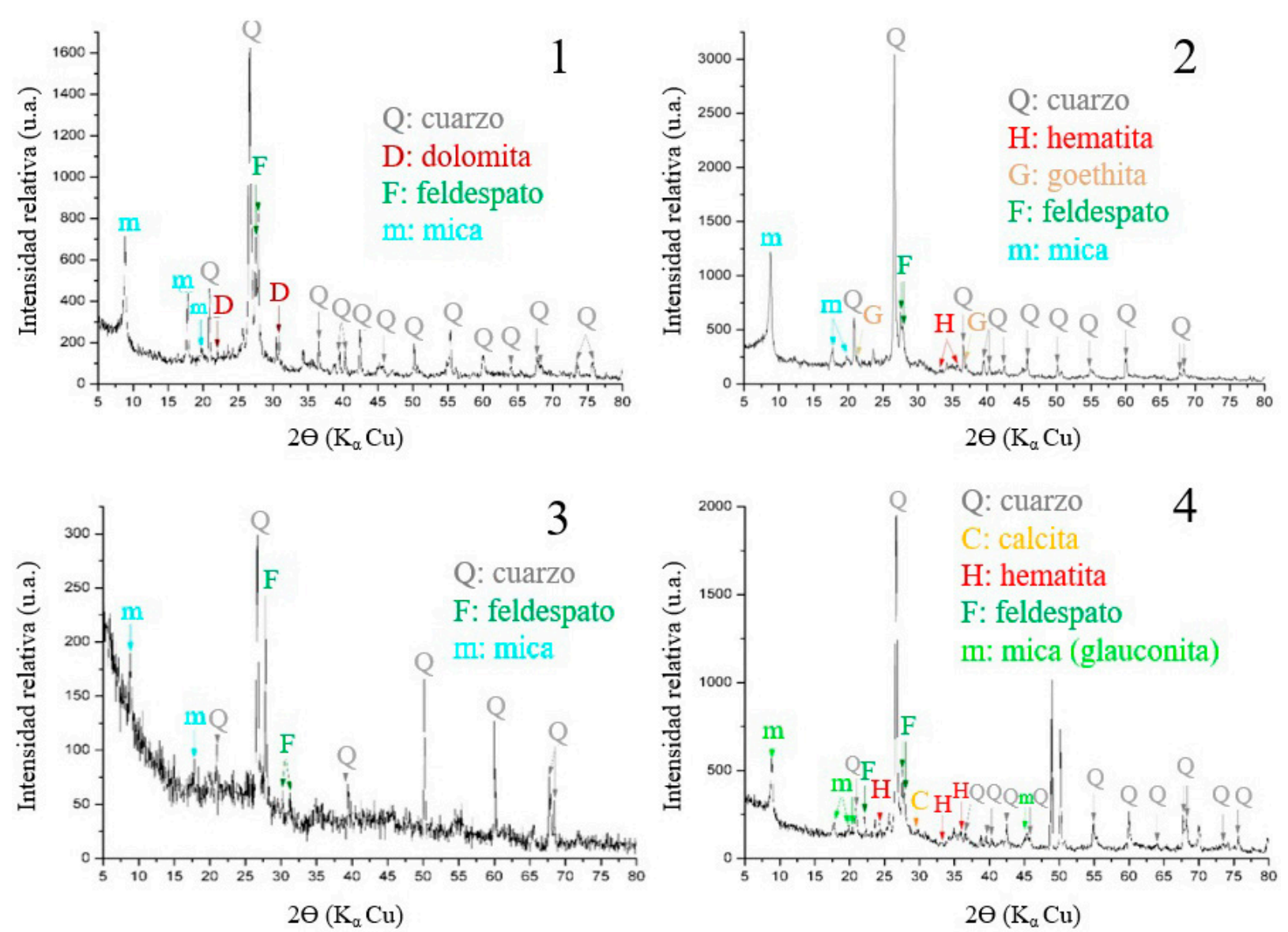

Fig. 10. Muestras procedentes del yacimiento de la Casa del Carpio (Belvis de la Jara, Toledo) donde se señalan los puntos donde se han efectuado los análisis y los difractogramas resultantes.

cerámicas con las superficies cuidadosamente alisadas, no bruñidas (Almagro-Gorbea, 1977: 454), sin que se haga alusión al acabado de las superficies del conjunto procedente de la necrópolis. No obstante, y a la vista de los ejemplares de Portaceli, en el mismo entorno arqueológico, no es raro que también hubieran tenido ese acabado bruñido; de hecho, de la observación que pudimos llevar a cabo de algunos fragmentos procedentes del poblado y depositados en el MAN, en algunos de ellos se apreciaba unos acabados que sin duda se podrían clasificar como bruñidos.

Esta circunstancia es muy llamativa por cuanto, como comentábamos, el bruñido dificulta mucho la adhesión de la pintura, lo que nos hace plantear la siguiente hipótesis. Si tenemos en cuenta que los vasos utilizados para ser pintados con bicromía obedecen siempre a formas concebidas en el Bronce Final, donde destacan los cuencos y las cazuelas carenadas, lo sobresaliente de estas producciones es 


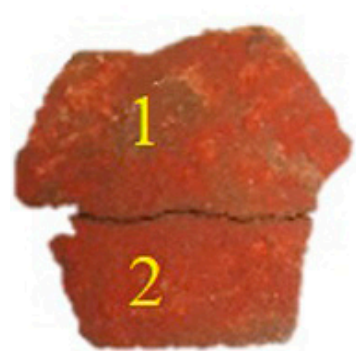

Ref. 639
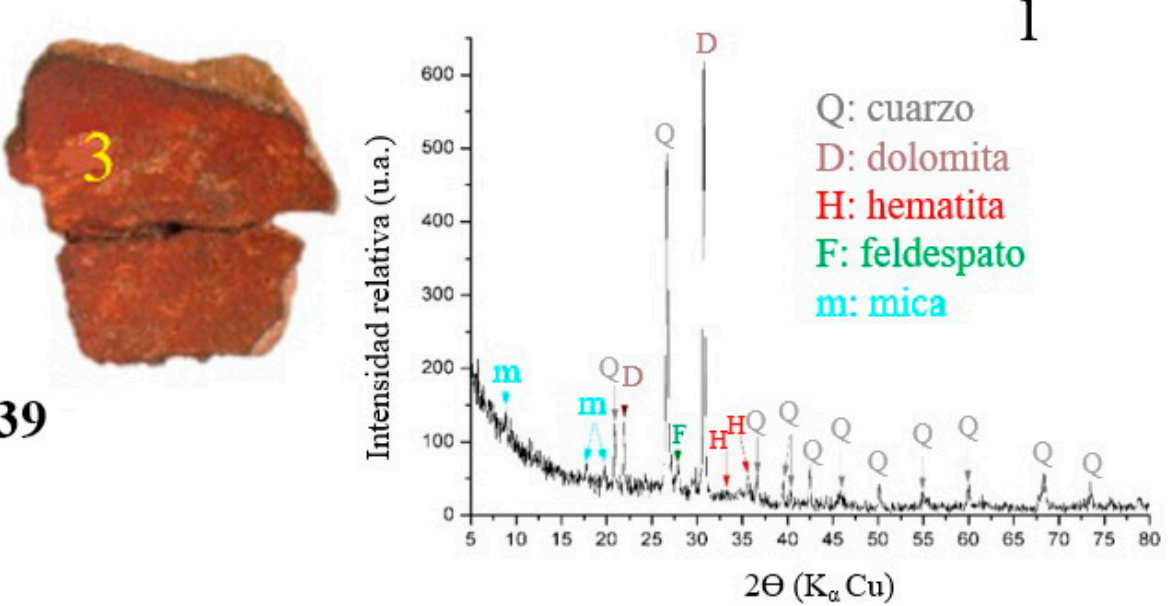

تِ

2

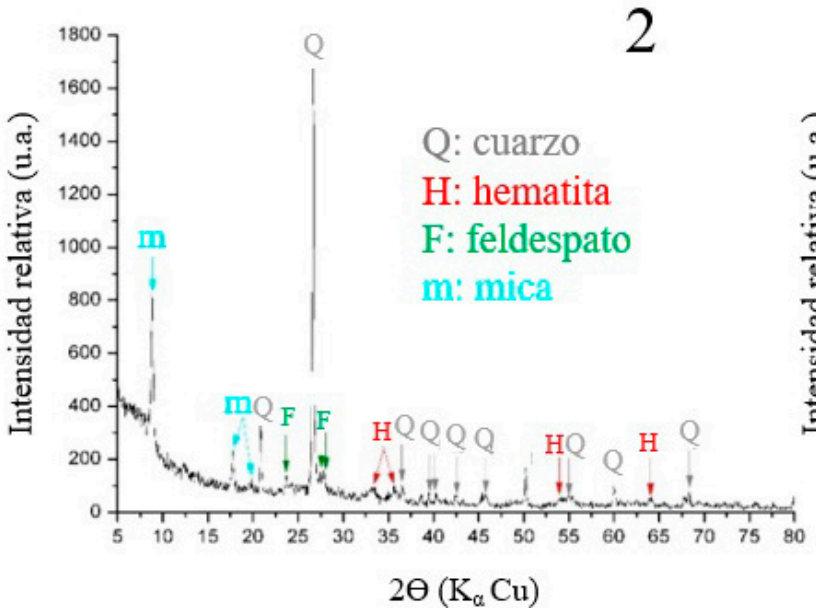

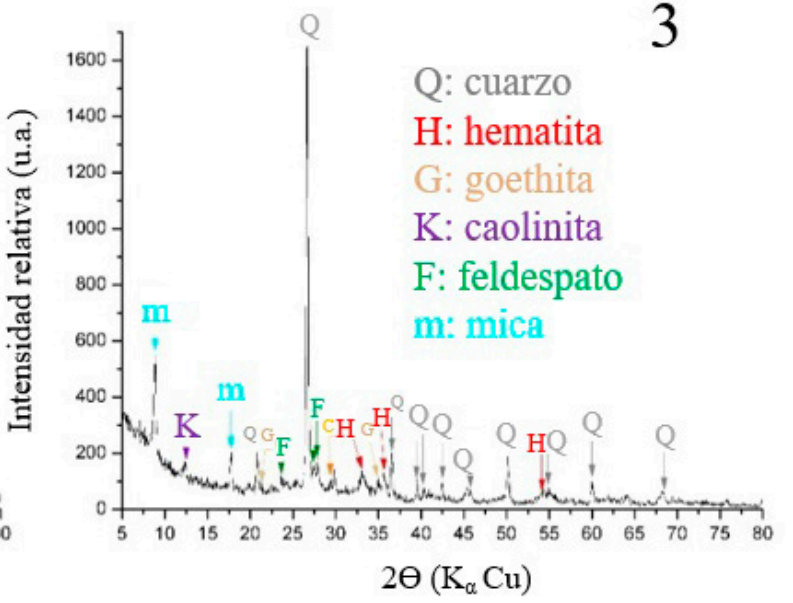

Fig. 11. Muestras procedentes del yacimiento de Santarém (Portugal) donde se señalan los puntos donde se han efectuado los análisis y los difractogramas resultantes.

sin duda la pintura que se les aplicó tras la cocción; de este modo, podría interpretarse que los vasos fueron elaborados para ser utilizados durante un tiempo sin ningún tipo de decoración pintada, y solo se les aplicaría la pintura en el último momento de su uso, cuando el recipiente ya estaba destinado a ser amortizado. Esto explicaría lo efímero de estas pinturas que se borran con solo manipularlas, así como que aparezcan en contextos muy determinados relacionados con necrópolis, caso de Sima Cabeza de la Fuente, El Carpio o Medellín, o en edificios de alto valor social, como en la Vivienda 2 de La Aldehuela, la cabaña del Nivel vi de Cerro San Pelayo, la cabaña de Alarcos, el edificio singular de La Bienvenida o la propia cabańa de Cerro Borreguero. 


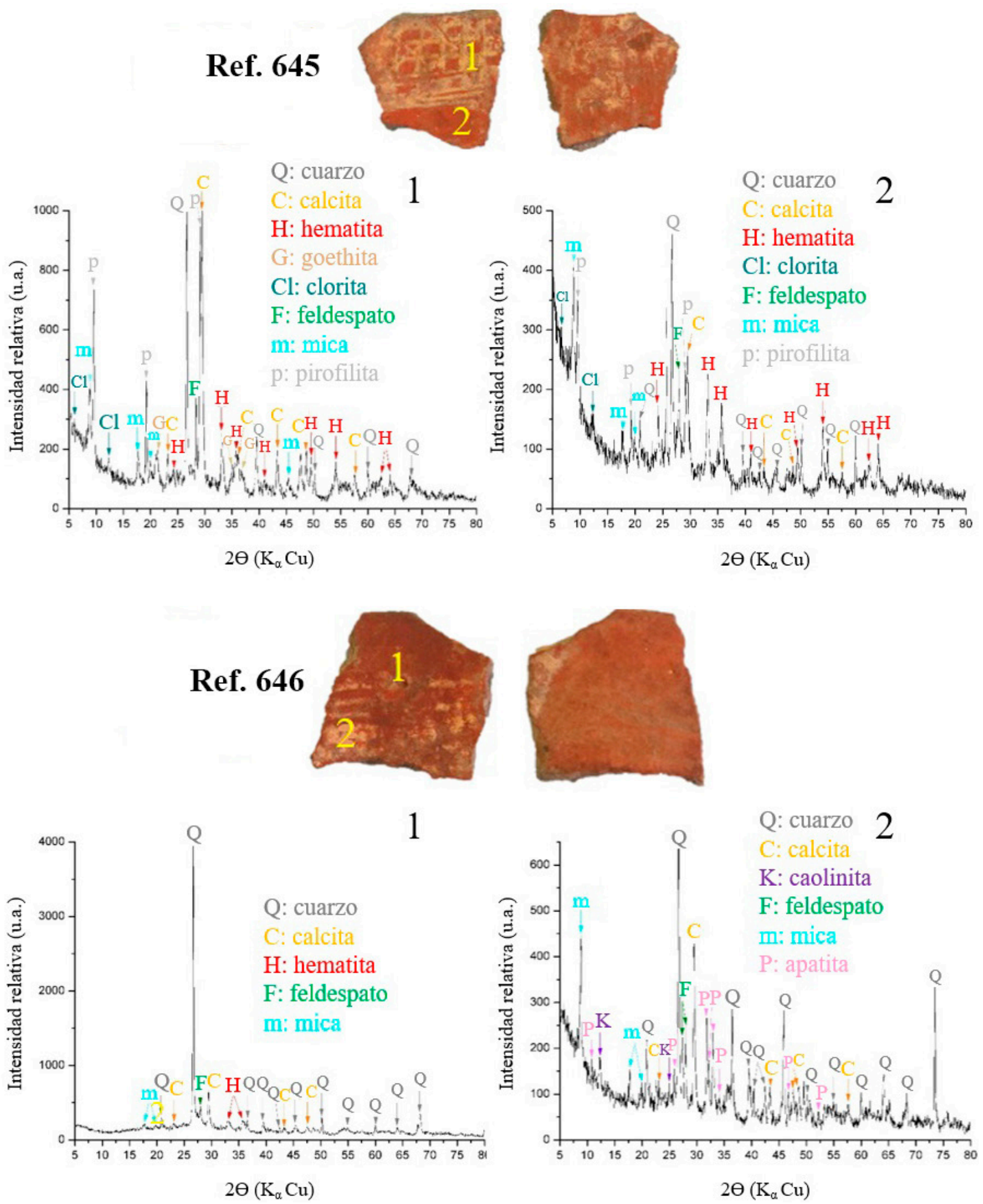



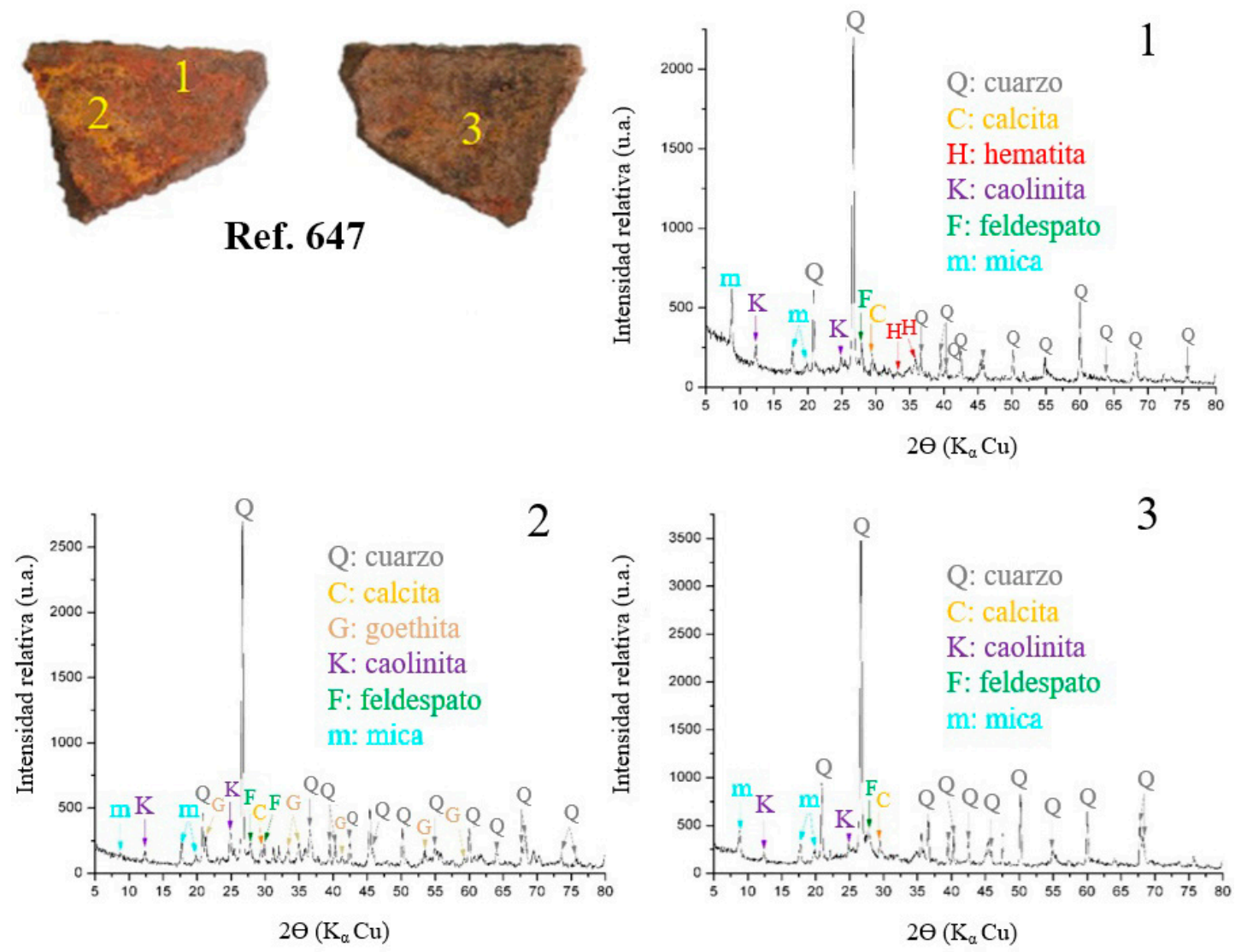

Ref. 649
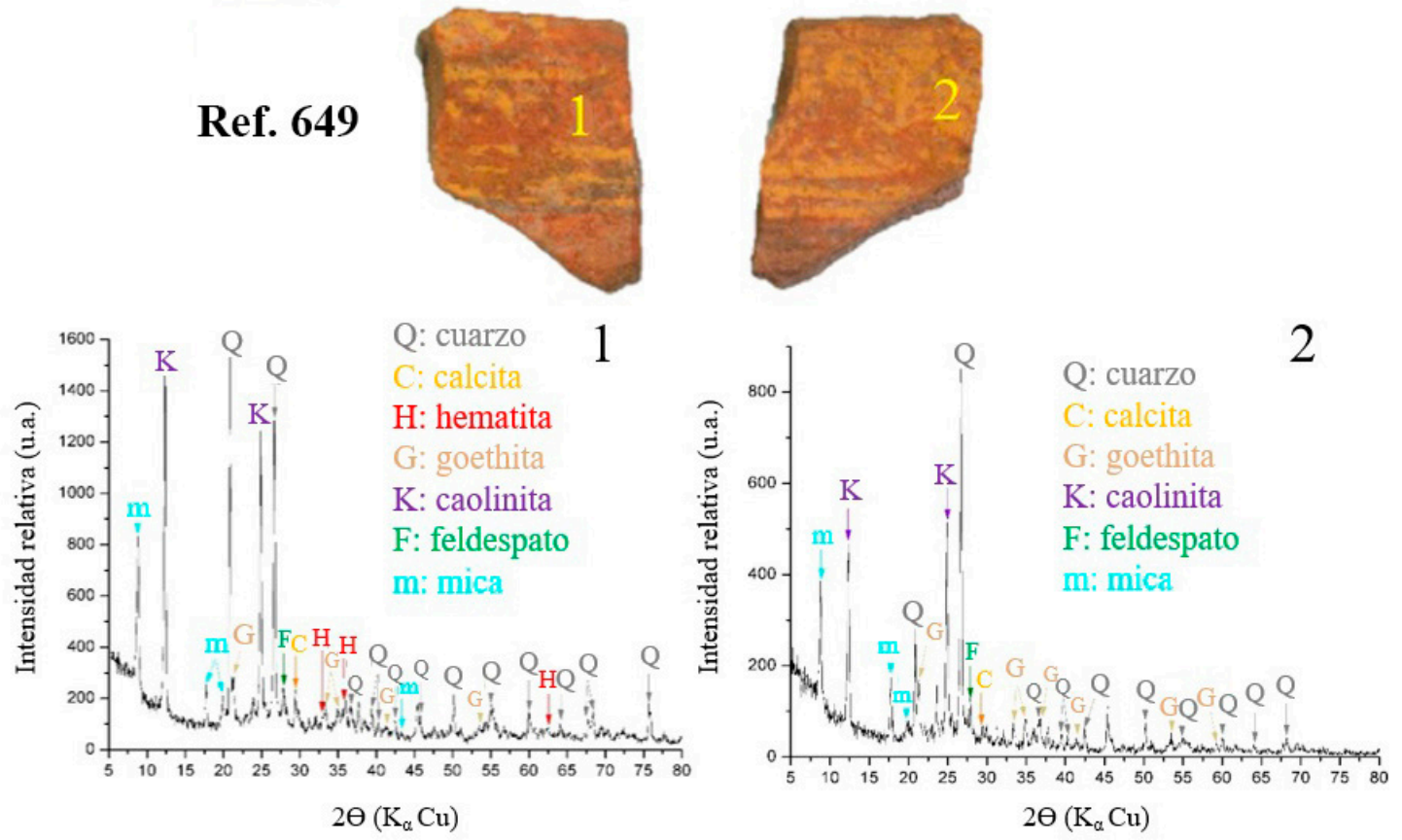

FIG. 12. Muestras procedentes del yacimiento de San Martín de Ledesma (Salamanca) donde se señalan los puntos donde se han efectuado los análisis y los difractogramas resultantes. 


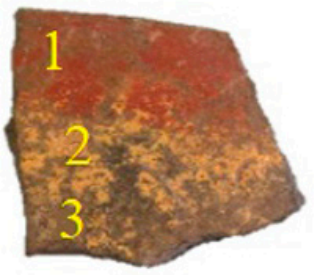

\section{Ref. 648}
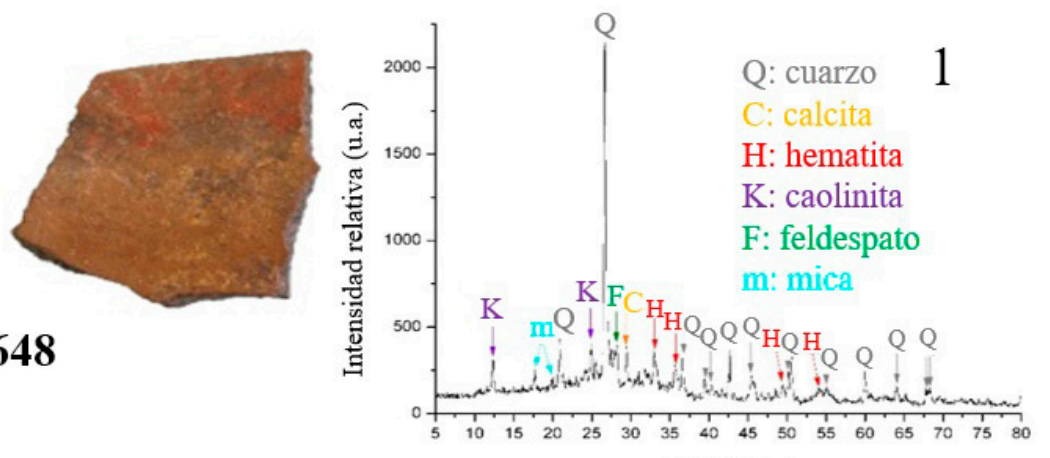

$2 \Theta\left(\mathrm{K}_{\alpha} \mathrm{Cu}\right)$
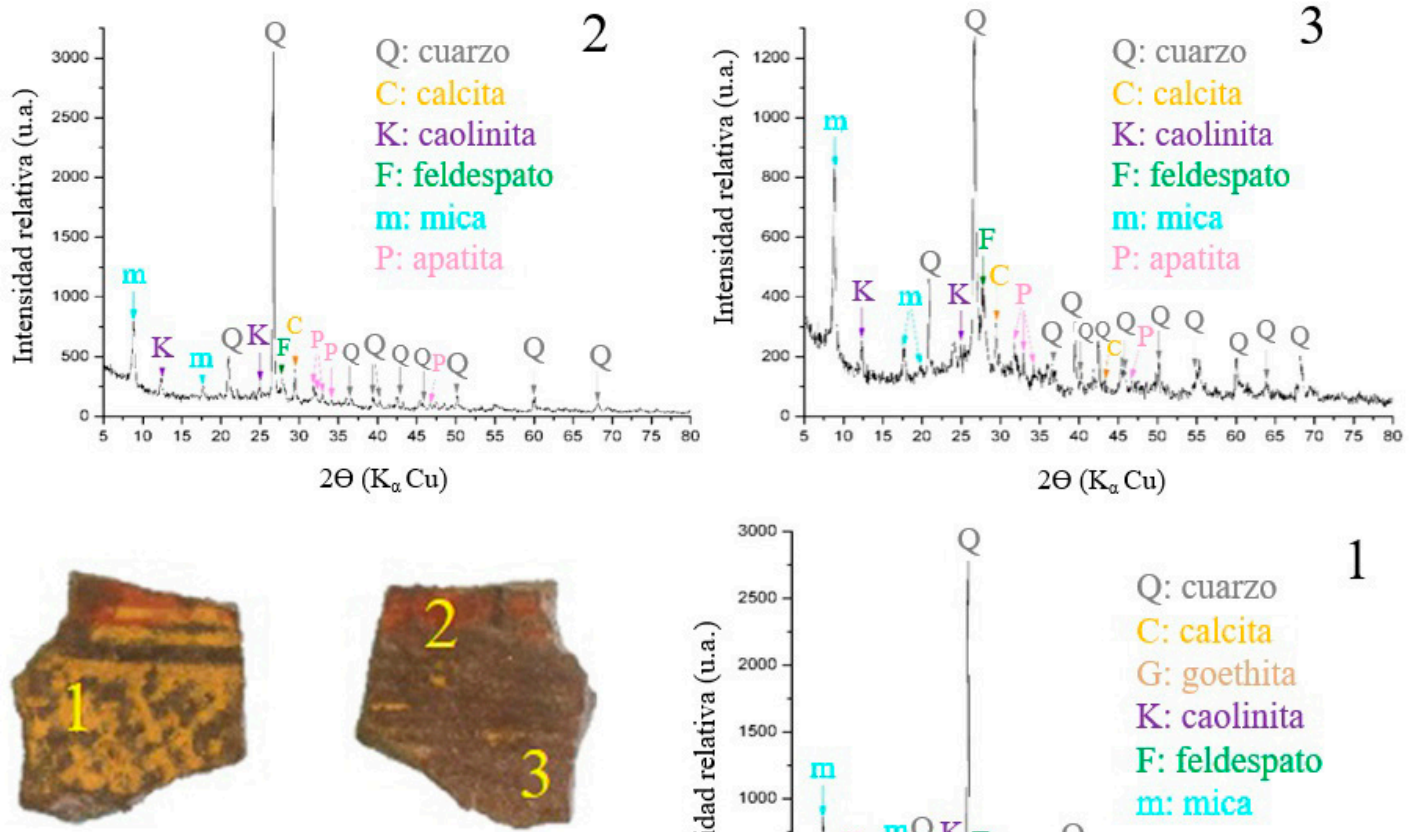

Ref. 650
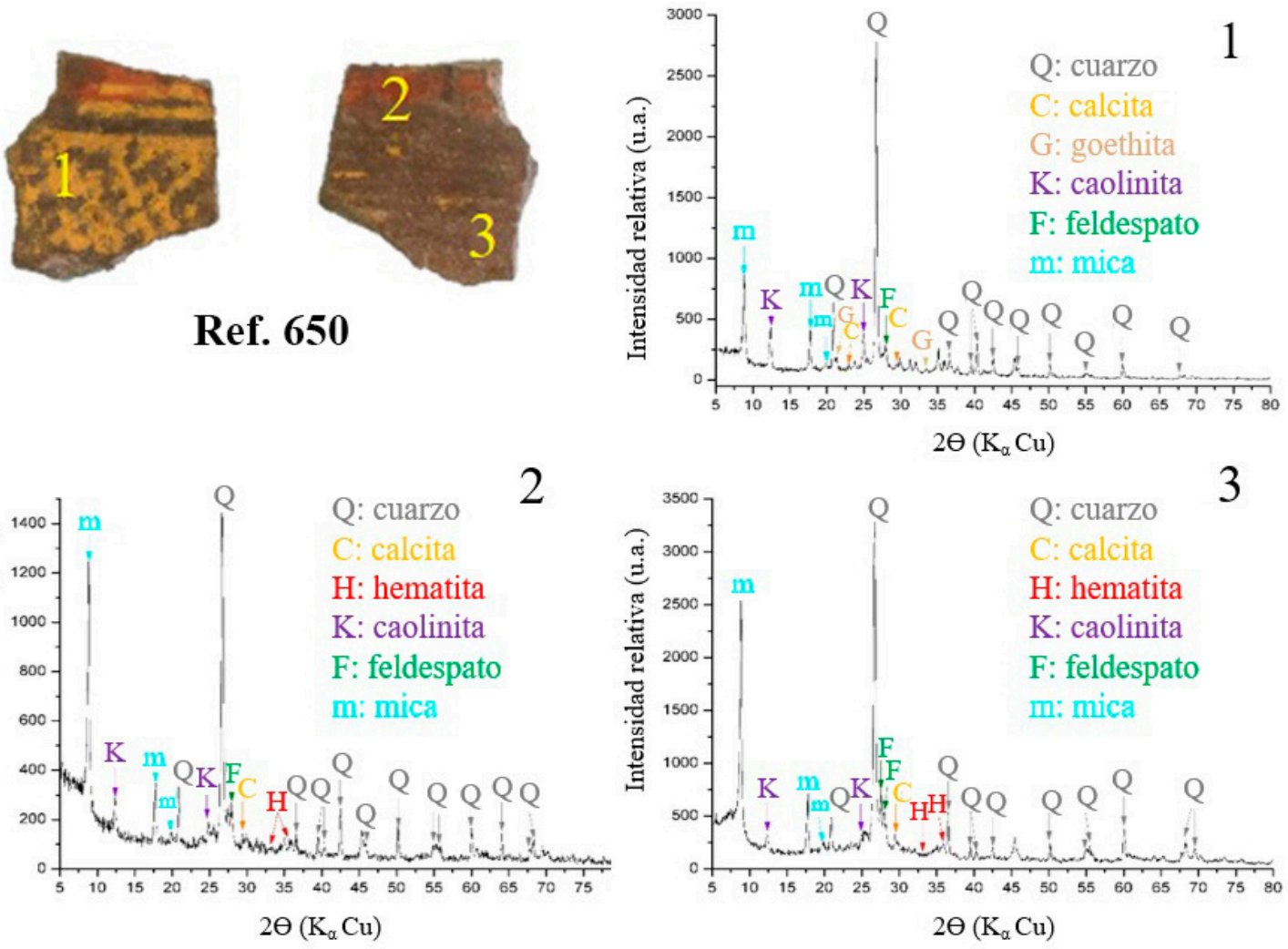

(c) Universidad de Salamanca

Zephyrus, LXXXII, julio-diciembre 2018, 119-148 

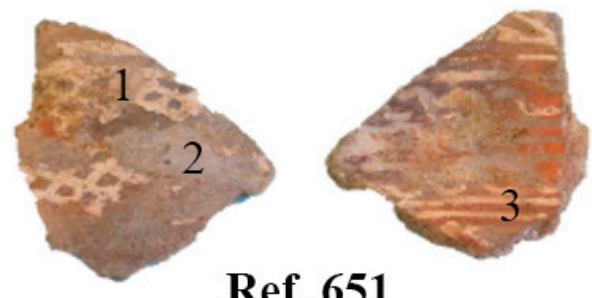

Ref. 651
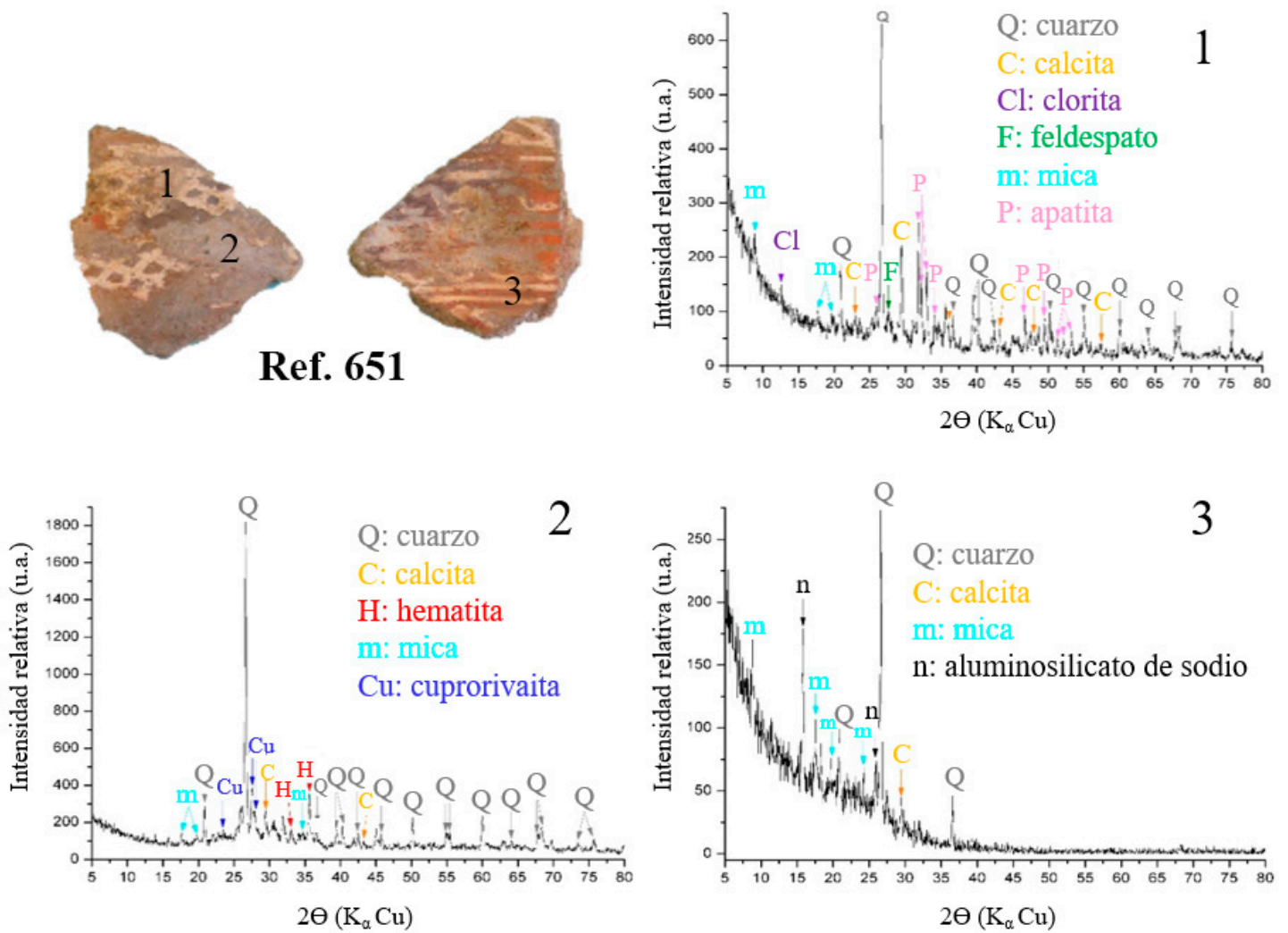

Fig. 13. Muestras procedentes del yacimiento de Cerro de San Pelayo (Martinamor, Salamanca) donde se señalan los puntos en los que se han efectuado los análisis y los difractogramas resultantes.
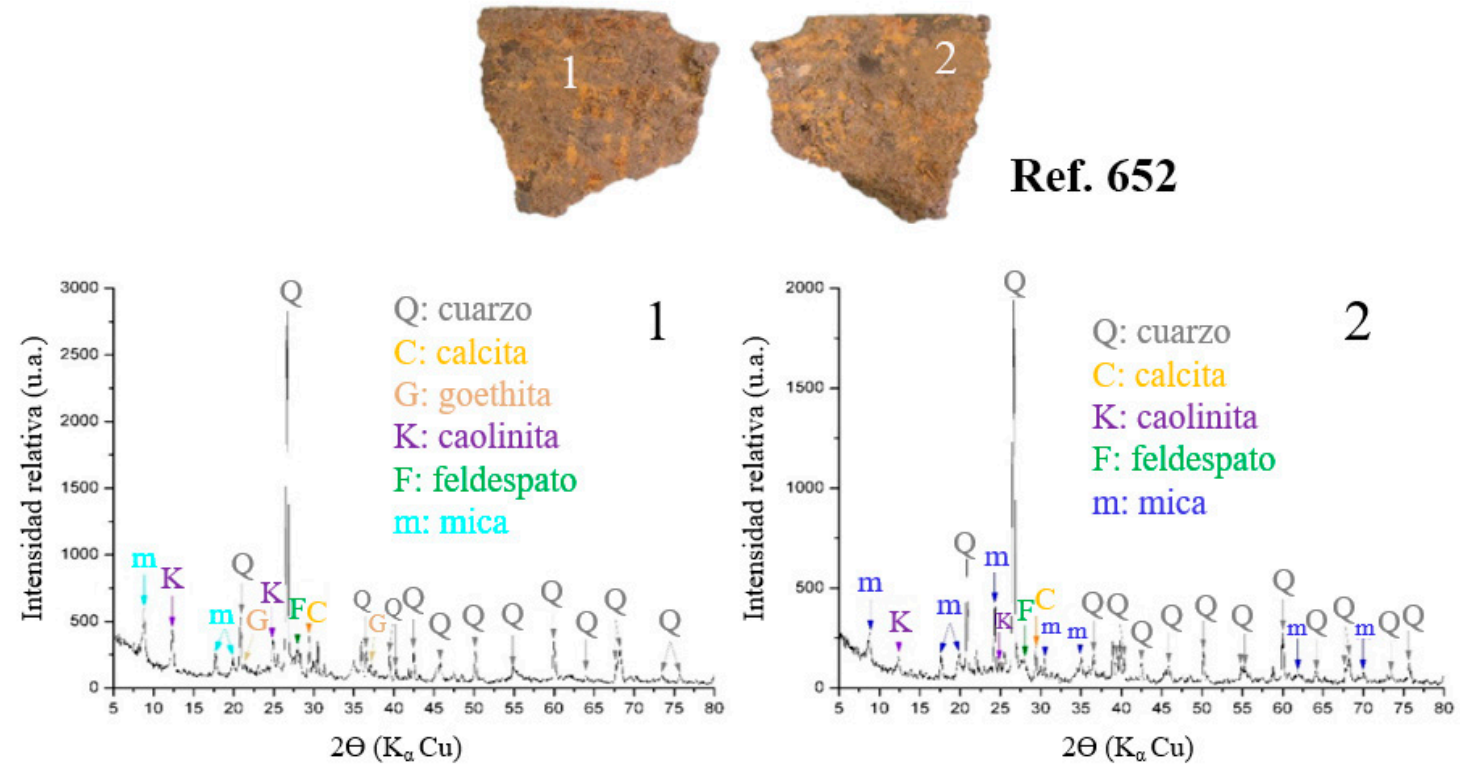

FIG. 14. Muestra procedente del yacimiento de Cerro de San Vicente (Salamanca) en la que se señalan los puntos donde se han efectuado los análisis y los difractogramas resultantes. 


\begin{tabular}{|c|c|c|c|}
\hline YACIMIENTO & Muestra & ZoNA DEL ANÁLISIS & COMPUESTOS CRISTALINOS IDENTIFICADOS \\
\hline \multirow{4}{*}{$\begin{array}{l}\text { Sima Cabeza de la Fuente } \\
\text { (Boniches, Cuenca) }\end{array}$} & \multirow{4}{*}{ Ref. 634} & A1: policromía amarilla sobre rojo & cuarzo, calcita, hematita, goethita, caolinita y mica (tipo moscovita) \\
\hline & & A2: policromía roja & cuarzo, hematita, caolinita, feldespato y mica (tipo moscovita) \\
\hline & & B1: policromía roja & cuarzo, calcita, hematita, feldespato y mica (tipo moscovita) \\
\hline & & B2: pasta cerámica de tono gris oscuro & cuarzo, hematita y mica (tipo illita) \\
\hline \multirow{10}{*}{ La Aldehuela (Zamora) } & \multirow{3}{*}{ Ref. 636} & 1: policromía roja & cuarzo, calcita, hematita, caolinita y mica (tipo moscovita) \\
\hline & & 2: policromía amarilla sobre rojo & cuarzo, calcita, caolinita, mica (tipo moscovita) y apatita (fluorapatita) \\
\hline & & 3: policromía amarilla sobre rojo & cuarzo, caolinita, mica (tipo moscovita) y apatita (fluorapatita) \\
\hline & \multirow{4}{*}{ Ref. 637} & 1: policromía roja & cuarzo, hematita, caolinita, feldespato y mica (tipo moscovita) \\
\hline & & 2: policromía amarilla/blanca sobre rojo & cuarzo, calcita, clorita, feldespato, mica (tipo moscovita) y apatita (fluorapatita) \\
\hline & & 3: policromía azul sobre rojo & cuarzo, calcita y azurita/cuprorivaita? \\
\hline & & 4: interior pasta & cuarzo, feldespato y mica (tipo moscovita) \\
\hline & \multirow{3}{*}{ Ref. 638} & 1: policromía amarilla sobre negro & cuarzo, hematita, goethita, caolinita, feldespato y mica (tipo moscovita) \\
\hline & & 2: policromía roja sobre negro & cuarzo, hematita, caolinita, feldespato y mica (tipo moscovita) \\
\hline & & 3: negro interior (pasta) & cuarzo, feldespato y mica (tipo moscovita) \\
\hline \multirow{3}{*}{ Santarém (Portugal) } & \multirow{3}{*}{ Ref. 639} & 1: pasta y policromía roja & cuarzo, dolomita, hematita, feldespato y mica (tipo moscovita) \\
\hline & & 2: policromía amarilla & cuarzo, hematita, feldespato y mica (tipo moscovita) \\
\hline & & 3: policromía amarilla & cuarzo, hematita, goethita, caolinita, feldespato y mica (tipo moscovita) \\
\hline \multirow{7}{*}{$\begin{array}{c}\text { Alarcos } \\
\text { (Ciudad Real) }\end{array}$} & \multirow{3}{*}{ Ref. 640} & 1: policromía roja sobre negro & cuarzo, hematita, goethita, caolinita, feldespato y mica (tipo moscovita) \\
\hline & & 2: policromía amarilla sobre negro & cuarzo, calcita, goethita, feldespato y mica (tipo moscovita) \\
\hline & & 3: negro interior & cuarzo, calcita, dolomita y mica (tipo moscovita) \\
\hline & \multirow{2}{*}{ Ref. 641} & 1: policromía roja sobre negro & cuarzo, calcita, dolomita hematita y mica (tipo moscovita) \\
\hline & & 2: negro interior & cuarzo, calcita, hematita y mica (tipo moscovita) \\
\hline & \multirow{2}{*}{ Ref. 642} & 1: policromía amarilla sobre negro & cuarzo, calcita, dolomita, goethita, feldespato y mica (tipo moscovita) \\
\hline & & 2: negro exterior & cuarzo, calcita, hematita, goethita y mica (tipo moscovita) \\
\hline \multirow{3}{*}{$\begin{array}{l}\text { Medellín } \\
\text { (necrópolis) }\end{array}$} & \multirow{3}{*}{ Ref. 643} & 1: policromía roja & cuarzo, hematita, feldespato y mica (tipo moscovita) \\
\hline & & 2: policromía amarilla sobre rojo & cuarzo, calcita, hematita, feldespato y mica (tipo moscovita) \\
\hline & & 3: costra blanca & cuarzo \\
\hline \multirow{2}{*}{$\begin{array}{l}\text { Medellín } \\
\text { (poblado) }\end{array}$} & \multirow{2}{*}{ Ref. 644} & 1: policromía amarilla sobre rojo & cuarzo, calcita, hematita, goethita, caolinita, feldespato y mica (tipo moscovita) \\
\hline & & 2: policromía roja & cuarzo \\
\hline \multirow{9}{*}{$\begin{array}{c}\text { San Martín } \\
\text { (Ledesma, Salamanca) }\end{array}$} & \multirow{2}{*}{ Ref. $645 \mathrm{~A}$} & 1: policromía amarilla sobre rojo & cuarzo, calcita, hematita, goethita, clorita, feldespato, mica (tipo moscovita) y piroflita \\
\hline & & 2: policromía roja & cuarzo, calcita, hematita, clorita, feldespato y mica (tipo moscovita), pirofilita \\
\hline & \multirow{2}{*}{ Ref. 646A } & 1: policromía roja & cuarzo, calcita, hematita, feldespato y mica (tipo moscovita) \\
\hline & & 2: policromía amarilla sobre rojo & cuarzo, calcita, caolinita, feldespato y mica (tipo moscovita), apatita (fluorapatita) \\
\hline & \multirow{3}{*}{ Ref. 647} & 1: policromía roja & cuarzo, calcita, hematita, caolinita, feldespato y mica (tipo moscovita) \\
\hline & & 2: policromía amarillo sobre rojo & cuarzo, calcita, goethita, caolinita, feldespato y mica (tipo moscovita) \\
\hline & & 3: policromía naranja & cuarzo, calcita, caolinita, feldespato y mica (tipo moscovita) \\
\hline & \multirow{2}{*}{ Ref. 649} & 1: policromía roja y amarilla & cuarzo, calcita, hematita, goethita, caolinita, feldespato y mica (tipo moscovita) \\
\hline & & 2: policromía amarilla & cuarzo, calcita, goethita, caolinita, feldespato y mica (tipo moscovita) \\
\hline \multirow{9}{*}{$\begin{array}{c}\text { Cerro de San Pelayo } \\
\text { (Martínamor, Salamanca) }\end{array}$} & \multirow{3}{*}{ Ref. 648} & 1: policromía roja & cuarzo, calcita, hematita, caolinita, feldespato y mica (tipo moscovita) \\
\hline & & 2: policromía amarilla & cuarzo, calcita, caolinita, feldespato y mica (tipo moscovita), apatita (fluorapatita) \\
\hline & & 3: pasta cerámica y policromía amarilla & cuarzo, calcita, caolinita, feldespato y mica (tipo moscovita), apatita (fluorapatita) \\
\hline & & 1: policromía amarilla sobre negro & cuarzo, calcita, goethita, caolinita, feldespato y mica (tipo moscovita) \\
\hline & Ref. 650 & 2: policromía roja sobre negro & cuarzo, calcita, hematita, caolinita, feldespato y mica (tipo moscovita) \\
\hline & & 3: interior negro & cuarzo, calcita, hematita, caolinita, feldespato y mica (tipo moscovita) \\
\hline & & 1: policromía blanca & cuarzo, calcita, clorita, feldespato y mica (tipo moscovita), apatita (fluorapatita) \\
\hline & Ref. 651 & 2: policromía azul sobre rojo & cuarzo, calcita, hematita, mica (tipo moscovita), cuprorivaita \\
\hline & & 3: policromía blanca y roja & cuarzo, calcita, mica (tipo moscovita), aluminosilicato de sodio \\
\hline
\end{tabular}




\begin{tabular}{|c|c|c|c|}
\hline YACIMIENTO & Muestra & ZoNa DEL ANÁLISIS & COMPUESTOS CRISTALINOS IDENTIFICADOS \\
\hline \multirow{2}{*}{$\begin{array}{c}\text { Cerro de San Vicente } \\
\text { (Salamanca) }\end{array}$} & \multirow{2}{*}{ Ref. 652} & 1: policromía amarilla & cuarzo, calcita, goethita, caolinita, feldespato y mica (tipo moscovita) \\
\hline & & 2: policromía amarilla & cuarzo, calcita, caolinita, feldespato, mica (tipo illita) \\
\hline \multirow{7}{*}{ Medellín (poblado) } & \multirow{3}{*}{ Ref. 653} & 1: rojo (pasta cerámica) & cuarzo, hematita, caolinita, feldespato y mica (tipo moscovita) \\
\hline & & 2: costra gris sobre rojo & cuarzo, hematita, goethita, caolinita, feldespato y mica (tipo moscovita) \\
\hline & & 3: policromía amarilla sobre rojo & cuarzo, hematita, goethita, caolinita, feldespato y mica (tipo moscovita) \\
\hline & \multirow{4}{*}{ Ref. 744} & 1: policromía roja más clara & cuarzo, caolinita, dolomita, feldespato y mica (tipo moscovita) \\
\hline & & 2: policromía roja más oscura & cuarzo, dolomita, hematita, caolinita, feldespato y mica (tipo moscovita) \\
\hline & & 3: policromía blanca sobre rojo & cuarzo, calcita, dolomita, caolinita, feldespato mica (tipo moscovita) \\
\hline & & 4: policromía rojo más oscura & cuarzo, calcita, dolomita, caolinita, feldespato y mica (tipo moscovita) \\
\hline \multirow{9}{*}{$\begin{array}{c}\text { Casa del Carpio } \\
\text { (Belvís de la Jara, Toledo) }\end{array}$} & \multirow{3}{*}{ Ref. 745} & 1: negro (pasta cerámica) & cuarzo, calcita, feldespato y mica (tipo moscovita) \\
\hline & & 2: policromía/costra blanca sobre negro & cuarzo, calcita, clorita, feldespato y mica (tipo moscovita) \\
\hline & & 3: policromía roja sobre negro & cuarzo, calcita, dolomita, hematita, feldespato y mica (tipo moscovita) \\
\hline & \multirow{2}{*}{ Ref. 746} & 1: pasta cerámica (marrón) & cuarzo, feldespato y mica (tipo moscovita) \\
\hline & & 2: policromía roja sobre la pasta & cuarzo, hematita, feldespato y mica (tipo moscovita) \\
\hline & \multirow{4}{*}{ Ref. 747} & 1: policromía roja sobre negro & cuarzo, dolomita, feldespato y mica (tipo moscovita) \\
\hline & & 2: policromía amarilla sobre negro & cuarzo, hematita, goethita, feldespato y mica (tipo moscovita) \\
\hline & & 3: policromía roja sobre negro & cuarzo, feldespato ymica (tipo moscovita) \\
\hline & & 4: negro (pasta cerámica) & cuarzo, calcita, hematita, feldespato y mica (glauconita) \\
\hline \multirow{3}{*}{ Sanchorreja (Ávila) } & \multirow{3}{*}{ Ref. 748} & 1: policromía roja sobre negro & cuarzo, calcita, feldespato y mica (tipo moscovita) \\
\hline & & 2: policromía amarilla sobre negro & cuarzo, calcita, hematita, goethita, caolinita, feldespato y mica (tipo moscovita) \\
\hline & & 3: negro (pasta cerámica) & cuarzo, calcita, hematita, feldespato y mica (tipo moscovita) \\
\hline
\end{tabular}

FIG. 15. Compuestos cristalinos identificados en los análisis efectuados sobre el lote de cerámicas seleccionadas para el estudio; en la tabla se recoge el yacimiento de procedencia y el número de referencia correspondiente al análisis en el laboratorio SECYR.

\section{Discusión sobre las cerámicas pintadas poscocción y su cronología}

El interés que han suscitado estas cerámicas ha sido constante desde que se publicaron los primeros ejemplares, si bien el primer y más profundo análisis de estos conjuntos se debe al hallazgo de las cerámicas estilo 'Medellín' halladas en la Cata Este realizada en el Castillo homónimo (Almagro-Gorbea, 1977: 454-461), donde se documentaron un buen número de fragmentos, en torno a 300 , que, sin embargo, son difíciles de datar por haberse encontrado en niveles de rápida deposición en una estratigrafía con una potencia de $5 \mathrm{~m}$ de profundidad (Almagro-Gorbea, 1977: 474); de hecho, estas cerámicas aparecen desde el Estrato XVI, el más antiguo, hasta el Estrato VII sin apenas variaciones técnicas o formales. Aunque el autor reconoce que los orígenes de estas cerámicas hay que buscarlos en el Bronce Final de la zona, los motivos decorativos los asocia al mundo orientalizante, haciendo especial hincapié en las cerámicas con motivos amarillos sobre fondo rojo por ser las más significativas del conjunto. Este tipo lo divide en dos subtipos en función de los ejemplares que se conocían hasta ese momento en la península: el tipo 'Meseta' y el tipo 'Andaluz' (Werner, 1990; Álvarez Sanchís, 1999: con bibliografía), fechando estas producciones hacia el s. viII a. C.

Según lo anterior, se deduce una cierta imposibilidad para establecer tipos por la compleja dispersión geográfica de los grupos establecidos (Blasco, 1981: 75-92); así, según esta autora, las cerámicas pintadas poscocción corresponderían a ambientes y cronologías muy diversas, iniciándose la moda en el s. VIII como consecuencia de la influencia de los Campos de Urnas, tanto por vía terrestre como marítima, lo que justificaría su presencia en el Sureste peninsular; su éxito en la I Edad del Hierro derivaría de la tradición que habría existido en la fase 
anterior de colorear las cerámicas incisas y de tipo 'Boquique', fechando las más antiguas de la Meseta en torno al s. vir a. C. (Blasco et al., 1988). Pero lo cierto es que este tipo de cerámica es cada vez más común en áreas de la Meseta, donde destaca por sus analogías formales y decorativas con el vaso del Cerro Borreguero el documentado en Sima Cabeza de la Fuente, en Boniches de la Sierra, Cuenca (Martínez Navarrete y Pérez de la Sierra, 1980: 65-94). Los primeros autores encuadran el vaso, hallado no obstante fuera de contexto, en el grupo de 'cerámicas pintadas hallstátticas' propuesto por Maluquer de Motes tras su estudio de los fragmentos procedentes de Castillejos de Sanchorreja (Maluquer de Motes, 1957: 286), fechándolo en los inicios de la I Edad del Hierro. En este sentido es de gran interés la revisión que en los años 90 del pasado siglo se hace de las cerámicas de Sanchorreja, cuando se incluyen otras procedentes de hallazgos más modernos (González-Tablas y Domínguez, 1995: 187-198); para estos autores, estas cerámicas no son extrameseteńas, sino que hunden sus raíces en el Bronce Final, pues se documentan en contextos de Cogotas I, donde en el Nivel v del yacimiento se localizaron varios fragmentos junto a cerámicas excisas y de tipo 'Boquique' (González-Tablas, 1983); sin embargo, datan estas cerámicas pintadas a partir del s. vir a. C. en sintonía con las de Medellín, de donde procederían.

Uno de los ejemplares más significativos de este conjunto es el de La Aldehuela, un yacimiento adscrito a la cultura de 'Soto de Medinilla' de la I Edad del Hierro (Santos, 1989, 2005). El vaso en cuestión apareció en el interior de la Vivienda 2 junto a un cuchillo afalcatado de hierro y una fíbula de doble resorte, por lo que asocian su cronología y origen a las de estilo 'Medellín', fechando el ejemplar en el s. vi a. C., dentro de Soto I (Santos, 1990: 225). Similar postura adopta Barrio (1993) sobre los ejemplares hallados en la plaza del Castillo de Cuéllar que guardan semejanzas decorativas con las de estilo 'Medellín', pues los diseños parece que se adaptan a los temas de raigambre mediterránea por parte de los artesanos indígenas. Estas cerámicas conviven con otras ya elaboradas a torno importadas del sur, por lo que fecha las pintadas poscocción también en Soto I, hacia el s. VI a. C.

Un problema diferente es el que presentan las cerámicas pintadas poscocción de la Meseta Sur, donde destaca muy especialmente el hallazgo de la tumba de El Carpio, en Belvís de la Jara (Toledo) (Pereira, 2008, con bibliografía anterior). En esta rica tumba se hallaron los cuencos pintados con perfiles muy similares a los indígenas del Bronce Final de Andalucía occidental y, por lo tanto, diferentes a los hallados en la Meseta Norte. Los motivos decorativos, sin embargo, recuerdan a los de la Meseta y el Guadiana. En una reciente aproximación al estudio de esta magnífica tumba, el autor fecha los cuencos en la primera mitad del s. vir a. C., y aunque mantiene que sus formas proceden de Andalucía occidental, defiende que la decoración bícroma derivaría del sector occidental de la península y la Meseta (Pereira, 2012: 209). También de la Meseta Sur proceden los hallazgos más recientes, algunos de yacimientos donde ya se habían documentado este tipo de cerámicas con anterioridad, caso del Cerro de las Cabezas, en Valdepeñas (Vélez y Pérez, 1987: lám. IV) o, sobre todo, La Bienvenida, en Almodóvar del Campo (Ciudad Real) (Zarzalejos et al., 1994: 173-174; Zarzalejos et al., 2011: 21). Pero de este yacimiento destaca especialmente el hallazgo de cerámicas pintadas monocromas en rojo tipo 'Guadalquivir I' o 'San Pedro II' junto a las de estilo 'Medellín' en los momentos más antiguos del edificio de la Fase xxv, junto a un lote de cerámicas donde el $92 \%$ están realizadas a mano, mientras que las elaboradas a torno son de clara procedencia mediterránea. También es significativo que las cerámicas de estilo 'Medellín' aparezcan con formas típicas del Bronce Final de la zona, como las cazuelas decoradas con bruñido interno. Estas cerámicas se fechan hacia finales del s. viII y siguieron activas en el yacimiento hasta la mitad del s. s. viI a. C., conviviendo con las primeras ánforas de tradición fenicia y en sintonía, pues, con las de estilo Medellín ${ }^{4}$.

En cuanto a la cronología de estas cerámicas, debemos basarnos exclusivamente en las que aparecen

4 Agradecemos a M. Zarzalejos que nos haya facilitado estos datos aún inéditos. 
perfectamente contextualizadas y en aquellos casos en los que se cuenta con dataciones absolutas que permiten afinar con precisión la fecha del contexto en el que han sido documentadas.

Entre los ejemplares contextualizados cabe destacar los casos de la necrópolis de Medellín (Torres, 2008) y la tumba de la Casa del Carpio de Belvís de la Jara (Pereira, 1989). Si la tumba de Casa del Carpio parece estar bien datada en la primera mitad del s. viI a. C. (Pereira, 2012: 201), las pintadas de la necrópolis de Medellín presentan algunos problemas de interpretación. Así pues, aunque se hallaron numerosos fragmentos de estas cerámicas, lo cierto es que tan solo algunos de ellos, once en concreto, formaban parte de algunos de los conjuntos funerarios individualizados, lo que permite otorgarles una fecha aproximada (Torres, 2008: 724). Los cuencos pintados estarían destinados a tapar urnas del tipo 'Cruz del Negro', pero, dado su estado fragmentario, también es posible que fueran empleados para realizar algún ritual que por el momento se nos escapa; en cualquier caso, las piezas recuperadas se han hecho derivar de las tipo 'San Pedro' II (Cabrera, 1981), por lo que se datarían entre finales del s. viII e inicios del viI a. C. (Torres, 2008: 732).

Disponemos de algunos datos más para afinar sobre la datación de estos vasos pintados; el primero lo podemos extraer del contexto donde apareció el ejemplar de La Aldehuela, un yacimiento adscrito a la cultura de Soto I y que su autor fecha en sintonía con Medellín en el s. vII, por haber aparecido junto a un cuchillo afalcatado de hierro y una fíbula de doble resorte que también hace proceder del sur peninsular (Santos, 1990: 232). Castillejos de Sanchorreja es uno de los primeros sitios donde la cerámica bícroma se documenta en contextos de Cogotas I, pues en el Nivel v de Sa-18 se localizaron varios fragmentos junto a cerámicas excisas y de tipo 'Boquique' (González-Tablas, 1983), si bien sus autores prefieren fecharlas a partir del s. viI para hacerlas coincidir con las de Medellín, de donde procederían; estas cerámicas pervivirían en Sanchorreja hasta el s. vi a. C. (González-Tablas y Domínguez, 1995: 195) y descartan, por lo tanto, su origen hallsttático (Maluquer de Motes,1957: 286).
Como puede deducirse, la datación de estos ejemplares es un tema de enorme complejidad por cuanto las cerámicas pintadas aparecen en yacimientos de la I Edad del Hierro en sus niveles más antiguos, pero, sin embargo, no podemos establecer si ya se pintaban en la fase anterior a pesar de que sí sabemos que ya existían los tipos cerámicos. Lo mismo ocurre con las cerámicas de El Carpio, pertenecientes al momento más antiguo de la tumba, si bien desconocemos si vienen de una tradición pasada. En ambos casos, las fechas más antiguas no sobrepasan el final del s. viII a. C., pero los tipos cerámicos sobre los que se aplicó la pintura sí son claramente de la fase anterior, de ahí que se haya optado en la mayor parte de los casos por clasificar estas cerámicas en la transición del Bronce Final al Hierro, perviviendo al menos hasta el s. vi a. C., si no después, en algunas zonas de ambas mesetas.

La hipótesis que establece que estas producciones pintadas son de la fase de transición entre el Bronce Final y la I Edad del Hierro queda corroborada a partir de los ejemplares hallados en unidades estratigráficas que cuentan con dataciones absolutas, un hecho que permite dar uniformidad cronológica al fenómeno que aquí se presenta. Al ejemplar del Cerro Borreguero, cuya datación absoluta se recoge en el primer epígrafe de este trabajo, debemos sumarle los resultados obtenidos en el Cerro de San Pelayo, en Martimamor (Salamanca) (Benet, 1990). Se trata de uno de los yacimientos más importantes de la Meseta Norte para estudiar este tipo de cerámicas pintadas poscocción. Su interés radica en el claro contexto en el que apareció el ejemplar, junto a dos recipientes completos lisos que se encontraban al lado del hogar de una cabaña. Esta información se completa con las mencionadas dataciones por ${ }^{14} \mathrm{C}$ que sitúan el hallazgo en torno al s. viII a. C.

Recientemente se han publicado varias dataciones absolutas de otro yacimiento salmantino, el Cerro de San Vicente, procedentes de varios carbones recogidos durante las campañas de los años 90 del pasado siglo y de 2006, que han permitido definir la existencia de cuatro fases de ocupación en el yacimiento, la más antigua o Fase I correspondiente a la transición entre el Bronce Final y la I Edad del 
Hierro donde, precisamente, se documentan los primeros fragmentos pintados sobre cerámicas de estilo 'Soto' (Blanco et al., 2017: 390-391).

También muy reciente es la publicación de un conjunto de vasos pintados poscocción procedente de Alarcos que sirven para ajustar aun más la dispersión geográfica y la concreción tipológica de estas cerámicas que ya habían sido tratadas en un trabajo anterior (García Huerta y Fernández Rodríguez, 2000: 58); sin embargo, ahora se incorporan nuevos ejemplares mejor contextualizados y con dataciones absolutas que permiten a los autores optar por acotarlas en dos grupos: el primero con cerámicas tipo 'Carambolo', mientras que el segundo grupo estaría integrado tanto por las monocromas como por las bícromas a tenor de que las formas y técnicas son prácticamente iguales; además, del análisis realizado sobre estas cerámicas halladas en el Sector III del poblado de Alarcos, se deduce que fueron elaboradas en el entorno del yacimiento (García Huerta y Morales, 2017: 111). Todas las cerámicas que aparecen junto al magnífico vaso pintado bícromo son a mano, destacando los fragmentos decorados con retícula bruñida, lo que otorga a estas producciones una fecha acorde con la transición del Bronce Final al Hierro que se ve corroborada por la tabla de dataciones absolutas que adjuntan en este trabajo (García Huerta y Morales, 2017: 112).

A esta documentación debemos sumar los fragmentos de cerámicas 'Tipo Carambolo' recientemente publicados, procedentes de la Beira Interior (centro de Portugal), cuyos análisis de C14 permiten fechar estas producciones en un momento de transición entre el Bronce Final y la I Edad del Hiero (Vilaça et al., 2018).

Por todo ello, parece que el fenómeno de las cerámicas pintadas poscocción con motivos geométricos sobre vasos realizados a mano pudo originarse hacia el s. viII a. C. en la costa atlántica del sur peninsular, en una etapa, pues, donde ya se estaba desarrollando la colonización fenicia. Sin embargo, debemos distinguir las cerámicas pintadas tipo 'Carambolo' de las que se documentan en las áreas periféricas de Tarteso, donde la moda debió de introducirse a partir de finales del s. vIII, si bien se prolonga por todo el viI a. C. En efecto, las pintadas tipo 'Carambolo', también presentes en el valle del Guadiana, son coetáneas de las bícromas y es posible que sean el resultado de una misma influencia de origen mediterráneo; sin embargo, el fenómeno de las bícromas, fundamentalmente de pigmentos rojos y amarillos, parece una expresión circunscrita a las áreas periféricas del Guadiana y del Tajo, cuya datación más antigua no sobrepasa el final del s. viII a. C., y desde donde se extendieron a la Meseta Norte en momentos muy tempranos, no después de los inicios del s. vir a. C., si bien se generalizaron a finales de este siglo y, sobre todo, en el s. vi a. C. Una manifestación, por lo tanto, muy dilatada en el tiempo que puede explicarse por la carga ritual que acompañó a estos vasos pintados.

Sabemos de la importancia de los vasos pintados del valle del Guadalquivir y Huelva por su presencia en varias tumbas y significativos edificios como el santuario del Carambolo, de donde toman su nombre. Destaca especialmente por su cronología el Túmulo i de la necrópolis de Las Cumbres (Ruiz Mata, 1991), donde se documentaron los primeros y numerosos vasos pintados tipo Guadalquivir (Córdoba, 2004), formando parte además de un ritual donde estos cuencos fueron amortizados sobre el túmulo de la necrópolis (Córdoba y Ruiz Mata, 2000: 762). Los recipientes empleados responden a formas que hunden sus raíces en el Bronce Final, seleccionándose los de mejor factura y acabado, un hecho muy similar al que sucede en los valles del Guadiana y del Tajo, así como en la Meseta. Más difícil es rastrear las vías de penetración de estas influencias decorativas. El hallazgo de cerámicas pintadas de estilo Medellín en Santarém y Abul (Arruda, 2005: 298) en fechas anteriores a las que se han podido documentar en Medellín, vuelve a poner sobre la mesa la enorme importancia que tuvo la colonización fenicia en el territorio comprendido entre el estuario del Tajo y la desembocadura del Sado (Arruda, 2000), desde donde parece que se organizó el comercio hacia el interior peninsular, tanto a través del Tajo como del Guadiana. Una zona que, por otra parte, ya tenía una relación con la Meseta Norte desde el Bronce Final como atestiguan 
las cerámicas de Cogotas I halladas en Santarém (Arruda y Da Sousa, 2015: 179) y que no eran extrañas en el sur peninsular (Castro-Martínez et al., 1995). Esta vía de penetración hacia el interior peninsular a través del Tajo se refuerza por la presencia de yacimientos de relevancia en su tramo medio, caso de Talaverilla (Salgado, 2017), Arroyo Manzanas (Moreno, 1990), Las Fraguas (Pereira, 2001), el Cerro de la Mesa (Chapa y Pereira, 2006) o, especialmente, El Carpio por exhibir el magnífico lote de cerámicas pintadas; y es posible que esta influencia se prolongue aguas arriba a otros sitios de la Comunidad de Madrid donde se han documentado cerámicas pintadas bícromas como ya hemos mencionado anteriormente.

La datación del vaso de Cerro Borreguero, de finales del s. viII o comienzos del viI a. C., y su técnica de elaboración y decoración están en total consonancia con los ejemplares de otros lugares del valle del Guadiana, donde destacan Medellín, La Bienvenida y Alarcos, que además conviven con cerámicas propias del Guadalquivir como las tipo Carambolo o con las primeras importaciones de cerámicas fenicias. Por lo tanto, debemos interpretar estas decoraciones geométricas pintadas como una versión local de una moda surgida en el valle del Guadalquivir contemporánea con la colonización fenicia. De hecho, en cada una de las zonas aquí tratadas, se mantienen las formas de las cerámicas más cuidadas, principalmente cuencos y cazuelas, heredadas del Bronce Final, sobre las que se practicó la decoración pintada. Las relaciones de estas zonas meridionales con la Meseta desde el Bronce Final, certificadas por la presencia de cerámicas de Cogotas I en un cada vez más numeroso elenco de yacimientos del sur peninsular, facilitaría esas relaciones desde fechas tempranas. Un caso muy significativo es el de las dos cazuelas halladas juntas procedentes de Portaceli; una de ellas presenta la decoración pintada, mientras que la otra, de forma muy similar, solo está bruñida, lo que certifica la contemporaneidad del fenómeno.

En cuanto a los motivos de las decoraciones pintadas, no cabe duda de que es un tema espinoso en el que se han adentrado pocos investigadores por la dificultad que conlleva su interpretación (Jully,

(C) Universidad de Salamanca
1966; Cáceres, 1997). No obstante, si la pintura fue aplicada en estos vasos antes de su amortización y estos fueron depositados en lugares de clara significación ritual, podríamos interpretar que los motivos geométricos estarían relacionados con el imaginario mitológico de estas gentes, inspirados en los primeros diseños del área tartésica.

\section{Conclusiones}

El hallazgo de la cazuela pintada del Cerro Borreguero (Zalamea de la Serena, Badajoz) en un contexto arqueológico claro nos ha invitado a estudiar el fenómeno de las cerámicas pintadas bícromas poscocción. Según los resultados obtenidos tras el análisis de un lote de cerámicas procedentes de un total de once yacimientos arqueológicos, podemos concluir que se trata de producciones realizadas a mano, cocidas en ambientes reductores y pintadas tras la cocción. En todos los ejemplos estudiados, la pintura ha sido fabricada a partir del empleo de óxidos de hierro, hematita para los tonos rojos y goethita para los amarillos; si bien, los ejemplos de la Meseta, concretamente los de Zamora y Salamanca, presentan una particularidad en sus pigmentos al haberse detectado el uso de biogénica o hueso calcinado con el objetivo de intensificar los colores. Así mismo, la dispersión que presentan los yacimientos seleccionados para este trabajo nos permite concluir que se trata de un fenómeno de raíz atlántica que se extiende entre los valles del Guadiana y el Duero, aproximadamente.

Algo más complejo de determinar es el hecho de que las cerámicas se fabricasen y se pintasen en un mismo momento. Aunque las formas cerámicas estudiadas derivan claramente del Bronce Final, parece que las decoraciones geométricas bícromas corresponden al impulso estilístico orientalizante que a partir del s. viII a. C. se generaliza en la península. Es por ello que pensamos que es muy posible que las cerámicas tuviesen un primer momento de uso y que, en un momento determinado, y en un contexto ritual, fuesen pintadas, pues la inconsistencia de la pintura aplicada tras

Zephyrus, LXXXII, julio-diciembre 2018, 119-148 
la cocción y sobre una superficie alisada o bruñida no permitiría su utilización como contenedor de alimentos o bebida.

En cuanto a su cronología, el hecho de contar para el estudio tanto con piezas contextualizadas como con ejemplares fechados por radiocarbono nos permite fijar el momento de producción de estas cerámicas pintadas en el período de transición entre el Bronce Final y la i Edad del Hierro.

\section{Bibliografía}

Almagro-Gorbea, M. (1969): La necrópolis de las Madrigueras, Carrascosa del Campo (Cuenca). Bibliotheca Praehistorica Hispana, 10. Madrid: Csic.

Almagro-Gorbea, M. (1977): El Bronce Final y el Periodo Orientalizante en Extremadura. Bibliotheca Praehistorica Hispana, 14. Madrid: csic.

Álvarez Romero, C. (2012): "Los pigmentos en la prehistoria: proyecto de experimentación térmica con óxidos e hidróxidos de hierro", Boletín de Arqueología Experimental, 9, pp. 25-42.

Álvarez Sanchís, J. (1999): Los Vettones. Biblioteca Arqueológica Hispana 1. Madrid: RAH.

Arruda, A. M. (2000): Los fenicios en Portugal. Fenicios $e$ indígenas en el centro y sur de Portugal (ss. VIII-VI a. C.). Cuadernos de Arqueología Mediterránea, 5-6. Barcelona.

Arruda, A. M. (2005): "Orientalizante e Pós-orientalizante no sudoeste peninsular: geografías e cronologías". En Celestino, S. y Jiménez, J. (eds.): El Periodo Orientalizante. Anejos Archivo Español de Arqueología, xxxv. Mérida: CSIC, pp. 277-304.

Arruda, A. M. y Da Sousa, E. (2015): "La Edad del Bronce Final en Alcáçova de Santarém (Portugal)", Trabajos de Prehistoria, 72 (1), pp. 176-187.

Baldini, M.; Cremonte, M.; Botto, I. y Díaz, M. (2005): "De felinos, pastas y pigmentos. La cerámica de Choya 68 desde una perspectiva arqueométrica". En La Cultura de La Aguada y sus expresiones regionales. Logroño, pp. 87-105.

BARRIO, J. (1993): "Estratigrafía y desarrollo poblacional en el yacimiento prerromano de la Plaza del Castillo (Cuéllar, Segovia)". En Romero, F.; SAnz, C. y EsCudero, Z. (eds.): Arqueología Vaccea. Estudios sobre el mundo prerromano en la cuenca media del Duero. Valladolid: JcyL, pp. 173-212.
BARrio, J. (2002): "El santuario de culto doméstico del poblado prerromano de Cuéllar (Segovia): un análisis del contexto arqueológico y de los elementos rituales", Madrider Mitteilugen, 43, pp. 79-122.

Beck, L.; Rousseliere, H.; Castaing, J.; Duran, A.; Levon, M.; Moignard, B. y Plassard, F. (2014): "First use of portable system coupling X-ray diffraction and $\mathrm{x}$-ray fluorescence for in-situ analysis of prehistoric rock art”, Talanta, 129, pp. 459-464.

Benet, N. (1990): "Un vaso pintado y tres dataciones de C-14 procedentes del Cerro de San Pelayo (Martinamor, Salamanca)", Numantia, III, pp. 77-94.

Blanco, A.; Alario, C. y Macarro, C. (2017): “The earliest villages in Iron Age Iberia (800-400 BC): a view from Cerro de San Vicente (Salamanca, Spain)", Documenta Praehistorica, XuIv, pp. 386-401.

Blasco, C. (1981): "Reflexiones sobre la cerámica pintada del Bronce Final y la I Edad del Hierro en la Península Ibérica", Cuadernos de Prehistoria y Arqueología de la UAM, 8, pp. 75-92.

Blasco, C.; Capilla, M. a L. y Calle, J. (1988): "Madrid en el marco de la Primera Edad del Hierro de la Península Ibérica", Cuadernos de Prehistoria y Arqueología de la UAM, 15, pp. 139-182.

Cabrera, P. (1981): "La cerámica pintada de Huelva", Huelva Arqueológica, v, pp. 317-335.

Cáceres, Y. E. (1997): "Cerámicas y tejidos: sobre el significado de la decoración geométrica del Bronce Final en la Península Ibérica”, Complutum, 8, pp. 125-140.

Carrasco, J.; Pachón, J. y Aníbal, L. C. (1986): “Cerámicas pintadas del Bronce Final procedentes de Jaén y Córdoba", Cuadernos de Prehistoria de la Univ. de Granada, 11, pp. 199-235.

Casado, M. (2015): La cerámica con decoración geométrica del Carambolo. Monografías SPAL Arqueología, xxi. Sevilla.

Castro-Martínez, P. V.; Micó, R. y Sanahuja, M. E. (1995): "Genealogía y cronología de la cultura Cogotas I", Boletin del Seminario de Estudios de Arte y Arqueología, 61, pp. 51-118.

Celestino, S. y Rodríguez González, E. (2017): “De lo invisible a lo visible. La transición entre el Bronce Final y la Primera Edad del Hierro en el valle medio del Guadiana”. En Celestino, S. y Rodríguez González, E. (eds.): Territorios comparados: los valles del Guadalquivir, el Guadiana y el Tajo en época tartésica. Mérida: csic, pp. 183-212.

Celestino, S. y Rodríguez González, E. (2018): “Cerro Borreguero. Un yacimiento clave para estudiar la transición entre el Bronce Final y el período tartésico 
en el valle del Guadiana", Trabajos de Prehistoria, 75 (1), pp. 172-180.

Cerdeñono, M. ${ }^{a}$ L. (1983): "Cerámica hallstáttica pintada en la provincia de Guadalajara". En Homenaje al Prof. M. Almagro Basch. Madrid, vol. II, pp. 157-165.

Chapa, T. y Pereira, J. (2006): "Un vado perdido. El Cerro de la Mesa (Alcolea del Tajo, Toledo)". En Miscelánea en Homenaje a V. Cabrera. Zona Arqueológica, 7. Madrid, vol. II, pp. 120-133.

Córdoba, I. (2004): "La cerámica pintada con motivos radiales del túmulo I de la necrópolis de Las Cumbres (El Puerto de Santa María, Cádiz)". En Actas II Encontro de Arqueología do Sudoeste Peninsular. Faro: Univ. do Algarve, pp. 131-139.

Córdoba, I. y Ruiz Mata, D. (2000): "Sobre la construcción de la estructura tumular del túmulo 1 de las Cumbres (Castillo de Doña Blanca)". En Actas IV Congreso Internacional de Estudios Fenicios y Púnicos. Cádiz: UCA, vol. II, pp. 759-770.

Eastaugh, N.; Walsh, V.; Chaplin, T. y Siddal, R. (2004): Pigment compendium: a dictionary of historical pigments. Oxford.

Frère, M. M.; González, M. I.; Di Lello, C.; Polla, G.; Freire, E.; Halac, E. B.; Reinoso, M.; Custo, G. y Ortiz, M. (2016): "Empleo de colorantes en coberturas de fragmentos de alfarería del río Salado bonaerense", Intersecciones en Antropología, 3, pp. 45-55.

García Huerta, R. y Fernández Rodríguez, M. (2000): "La génesis del mundo ibérico en la Submeseta Sur: el tránsito del Bronce Final-I Edad del Hierro en Alarcos", Cuadernos de Prehistoria y Arqueología de la UAM, 26, pp. 47-68.

García Huerta, R. y Morales, F. J. (2017): "El poblado de Alarcos (Ciudad Real) en los inicios del I milenio a. C.: estructuras y materiales cerámicos", Trabajos de Prehistoria, 74 (1), pp. 108-126.

González Prats, A. (1983): El poblamiento antiguo de Crevillente, Alicante. Estudio arqueológico. Alicante: UAL.

González-Tablas, F. J. (1983): Los Castillejos de Sanchorreja y su incidencia en las culturas del Bronce Final $y$ de la Edad del Hierro de la Meseta Norte. Salamanca: USAL.

González-Tablas, F. J. y Domínguez, A. (1995): “Cerámicas pintadas postcocción: fósil guía y conjunto cultural", Zephyrus, xLviII, pp. 187-198.

Hradil, L. D.; Grygar, T.; Hradilová, J. y BezdičKA, P. (2003): "Clay and iron oxide pigments in the history of painting", Applied Clay Science, 22 (5), pp. 223-236.

(C) Universidad de Salamanca
JimÉnez Ávila, F. J. y HabA, S. (1995): "Materiales tartésicos del solar de Portaceli (Medellín, Badajoz)", Complutum, 6, pp. 235-244.

Judson, S. (1959): "Paleolithic paint", Science, 130 (3377), p. 708.

Jully, J. J. (1966): "Thèmes ornementaux des poteries non méditerranéennes peintes en France sud et en Péninsule Ibérique, Bronze Final et premier Âge du Fer". En Maluquer de Motes, J. (coord.): Problemas de la Protohistoria y de la Etnología vasca. Symposium de Prehistoria Peninsular, 4. Pamplona: Gob. de Navarra, pp. 149-164.

Kakoulli, I. (2002): "Late Classical and Hellenistic painting techniques and materials: a review of the technical literature". Studies in Conservation, 47 (1), pp. 56-67.

López Jiménez, O. y Benet, N. (2004): "Nuevos resultados en la investigación sobre la 'Plaza de Toros' del Cerro de San Pelayo (Martinamor, Salamanca): un enterramiento tumular con inhumación en los inicios del primer Milenio en el área occidental de la Meseta Norte", Trabajos de Prehistoria, 61 (1), pp. 157-173.

Maluquer de Motes, J. (1954): El yacimiento hallstáttico de Cortes de Navarra. Estudio crítico I. Pamplona.

Maluquer de Motes, J. (1957): "La cerámica pintada hallstáttica del nivel inferior del Castro de Sanchorreja (Ávila)", Zephyrus, viII (2), pp. 286-287.

Marte, F.; Acevedo, V. J. y Mastrangelo, N. (2012): "Técnicas arqueométricas combinadas aplicadas al análisis de diseños de alfarería tricolor de quebrada de Humahuaca, Jujuy, Argentina”, Boletín del Museo Chileno de Arte Precolombino, 17 (2), pp. 53-64.

Martínez Navarrete, M. I. y Pérez de la Sierra, J. V. (1980): Sima 'Cabeza de la Fuente' Boniches de la Sierra (Cuenca). Noticiario Arqueológico Hispano, 10. Madrid.

Molina, F. (1978): "Definición y sistematización del Bronce Tardío y Final en el Sudeste de la Península Ibérica", Cuadernos de Prehistoria de la Univ. de Granada, 10, pp. 159-232.

Moreno, F. (1990): "Notas al contexto arqueológico de Arroyo Manzanas (Las Herencias, Toledo)". En Actas I Congreso de Arqueología de la provincia de Toledo. Toledo: Diput. de Toledo, pp. 277-308.

Pereira, J. (1989): "Nuevos datos para la valoración del hinterland tartésico. El enterramiento de la Casa del Carpio (Belvís de la Jara, Toledo)". En Tartessos. Arqueología protohistórica del Bajo Guadalquivir. Sevilla, pp. 395-409. 
Pereira, J. (2001): "Primeras noticias sobre la toréutica orientalizante en la Península Ibérica. El informe de Jiménez de la Llave", Complutum, 12, pp. 345-354.

Pereira, J. (2008): "La tumba de Casa del Carpio y el comercio en el valle del Tajo". En Arqueología vetona. La Meseta occidental en la Edad del Hierro. Madrid: Comunidad de Madrid, pp. 115-124.

Pereira, J. (2012): "El enterramiento femenino de la Casa del Carpio (Toledo)". En Prado, L. (ed.): La arqueología funeraria desde una perspectiva de género. Colección Estudios, 145. Madrid: UAM, pp. 201-2014.

Rodríguez González, E. (2018): El poblamiento del valle medio del Guadiana durante la I Edad del Hierro. Bibliotheca Praehistorica Hispana, xxxIv. Madrid: CsIC.

Ruiz Mata, D. (1986): "Puntualizaciones sobre la cerámica pintada tartésica del Bronce Final-estilo Carambolo o Guadalquivir I", Cuadernos de Prehistoria y Arqueología de la UAM, 11-12, pp. 245-253.

Ruiz Mata, D. (1991): "El túmulo 1 de la necrópolis de las Cumbres", Treballs del Museu Arqueologic d'Eivissa e Formentera, 24, pp. 207-220.

Salgado, J. A. (2017): “Talavera la Vieja (Cáceres), un asentamiento orientalizante en la cuenca del río Tajo”. En Celestino, S. y Rodríguez GonzÁlez, E. (eds.): Territorios comparados: los valles del Guadalquivir, el Guadiana y el Tajo en época tartésica. Madrid: csic, pp. 393-410.

SAntos, J. (1989): "Resumen de la segunda campaña de excavación en el yacimiento de la I Edad del Hierro de la Aldehuela (Zamora)", Anuario del Instituto de Estudios Zamoranos Florián del Campo, pp. 171-180.

Santos, J. (1990): "Una yacimiento de la I Edad del Hierro con cerámicas pintadas en la Aldehuela (Zamora)". En Actas I Congreso de Historia de Zamora. Zamora: IEZFo, pp. 225-240.

SAntos, J. (2005): "Motivos ornamentales orientalizantes en la cerámica de la I Edad del Hierro en la Meseta Norte: La Aldehuela (Zamora)". En Celestino, S. y Jiménez, J. (ed.): El Periodo Orientalizante. Anejos de Archivo Español de Arqueología, xxxv. Mérida: CSIC, pp. 1025-1038.

Swann, C. P.; Caspi, S. y Carlson, J. (1999): “Six stirrup handled Moche ceramic vessels from preColombian Peru: a technical study applying PIXE spectrometry", Nuclear Instruments and Methods in Physics Research Section B: Beam Interactions with Materials and Atoms, 150 (1), pp. 571-575.

Torres, M. (2008a): "Cerámica pintada de tipo Medellín”. En Almagro-Gorbea, M. (dir.): La necrópolis de Medellín. II. Estudio de los hallazgos. Madrid: RAH, pp. 724-733.

Torres, M. (2008b): "Urnas de tipo Cruz del Negro". En Almagro-Gorbea, M. (dir.): La necrópolis de Medellín. II. Estudio de los hallazgos. Madrid: RAH, pp. 631-654.

VAliente, S. (1973): “Nuevo yacimiento de cerámica pintada de la I Edad del Hierro en España”. En Crónica XII Congreso Arqueológico Nacional. Zaragoza, pp. 333-340.

Vélez, J. y Pérez Avilés, J. (1987): “El yacimiento protohistórico de Cerro de las Cabezas (Valdepeñas)”, Oretum, III, pp. 167-196.

Vilaça, R.; Soares, I.; Osório, M. y Gil, F. (2018): “Cerâmicas pintadas de 'Tipo Carambolo' na Beira Interior (centro de Portugal)”, SPAL, 27 (2), pp. 55-88.

WERnER, S. (1990): La cerámica pintada geométrica del Bronce Final y de la Primera Edad del Hierro. Madrid: Ed. La Muralla.

Zarzalejos, M.; Fernández Ochoa, C.; Esteban, G. y Hevia, P. (1994): "Las raíces de Sisapo (La Bienvenida, Ciudad Real)". En La ciutat en el món romà (XIV Congreso Internacional de Arqueología Clásica). Tarragona: csic, pp. 150-152.

Zarzalejos, M.; Fernández Ochoa, C. y Hevia, P. (2011): Investigaciones arqueológicas en Sisapo, capital del cinabrio hispano (I). La decoración musivaria de la Domus de las Columnas Rojas (La Bienvenida, Almodóvar del Campo-Ciudad Real). Madrid: UNED. 